$1-1-1945$

\title{
Some soil properties which influence the use of land in West Virginia
}

Richard M. Smith

G. G. Pohlman

D. R. Browning

Follow this and additional works at: https://researchrepository.wvu.edu/ wv_agricultural_and_forestry_experiment_station_bulletins

\section{Digital Commons Citation}

Smith, Richard M.; Pohlman, G. G.; and Browning, D. R., "Some soil properties which influence the use of land in West Virginia" (1945). West Virginia Agricultural and Forestry Experiment Station Bulletins. 321.

https://researchrepository.wvu.edu/wv_agricultural_and_forestry_experiment_station_bulletins/324 
Digitized by the Internet Archive in 2010 with funding from

Lyrasis Members and Sloan Foundation 


\title{
Some Soil Properties Which Influence the Use of Land in West Virginia
}

\author{
BY \\ R. M. SMITH \\ G. G. POHLMAN \\ AND \\ D. R. BROWNING
}

Agricultural Experiment Station

College of Agriculture, Forestry, and Home Economics

West Virginia University

C. R. Orton, Director

Morgantown

In Cooperation with the Soil Conservation Service

United States Department of Agriculture 
Introduction

Previous work

Fleld sampling and descriptions

Iaboratory methods

6

Soll-profile properties

9

Organic matter

28

Acidity, base saturation, and buffering

34

Available phosphorus

53

Available potash

54

Discussion

62

Summary and conclusions

65

B1bliography

67 


\section{R. M. Smithl, G. G. Pohlman ${ }^{2}$, and D. R. Browning ${ }^{3}$}

The importance of the soil in planning and putting into operation those practices wh1ch are necessary to insure adequate conservation and increased production make it especially desirable to present all avallable information regarding the soils of West Virginia at this time. Present information is too meager for more than a preliminary report, but an outline of the general objectives, methods of study, interrelations among metbods, and skeletal results is required to provide a background for any later revisions and detail. It is hoped that some of this background material will help to clear away any confusion which may exist regarding the meaning of certain soll properties and measurements as applied to West Virginia conditions.

Some so1 properties can be seen but not measured. Others are measurable but cannot be seen. The meanings of some are well understood; others are questionable or obscure. All of these and many more complications enter into the study of solls as related to soll management for increased crop growth and for soil conservation. One question answered raises new questions. Progress in the field means new demands on the laboratory, an new laboratory techniques require field samples to interpret their meaning. Farm and fleld response follows small plot results, or the reverse, and invariably there is an interlocking of all the approaches to a particular problem. Soil, crop, climate, animals, and man in their varied forms are all responsible for the yielc from the land, and new developments must finally satisfy them all.

The role of the soil in agricultural problems varies greatly in importance. Sometimes it is dominant; at other times it seems incidental to the crop or to the practice

1. Project Supervisor, Research Division, Soll Conservation Service, West Virginia Agricultural Experiment Station.

2. Head of Department of Agronomy and Genetics, West Virginia University.

3. Junior Soll Surveyor, Research Division, Soil Conservation Service; and Assistant in Agronomy, West Virginia Agricultural Experiment Station. 
of man. In any case, soil is the foundation of the farm, and its use is of utmost importance in determinirg the continuation of various farm enterprises. As the understanding of the soil increases, there will be greater onnortunity to use it wisely.

The results reported here were obtained by studying soils as they occur in the field and by collecting samples from areas representing typical conditions throughout the state. All factors in the field that cen be seen are described in specific terms. These observations and descriptions are shared by several individuals, and the soil distirctions are made to conform with the present systems of classification and mapping by the Soi] Survey Division of the Bureau of Plant Industry, Soils, and Agricultural Engineering and the Soil Conservation Service. Samples are commonly taken in roadcuts or excavations to afford detailed observation. Pasture areas are most frequently chosen beceuse of the important role of such land and the relative univormity afforded with respect to treatment, erosion, and use. Timber, clean-tilled, or hay lands are, however, sampled at times if the soll conditions seem especially sifnificant or typical of problem areas. In any case, attention is given to present plant growth and to root development celative to the soil.

The samples collected.are taken to the laboratory and studied by chemical and physical means in such detail as seems desirable to assist in characterizing them. Standard laboratory procedures are used in most cases, but adaptations are applied where standard methods seem to be inacequate. Field notes and laboratory data are compiled, studied, and compared with results from plot studies and with theory to form a better framework of facts and understanding.

\section{P.FVIOUS MORK}

The soil-survey maps and bulletins which have been completed by the Soil Survey Division of the United States Department of Agriculture, Bureau of Chemistry and Solls, and by the West Vireinia Geological Survey for every county in the state provide fundamental field information regardirg soils and slopes in west Virginia. From the laboratory approach, three bulletins of the West Vireinia igricultural ixperiment Station provide basic analytical data $(5,12,42)$ These cover chemical analyses of 485 soil samples represeriing important soil series within the state and serve as $a$ 
valuable source of information. They show that average limestone solls are less acid besides contalning more total phosphorus and nitrogen than the soils derived from sandstones and shales. All the soils analyzed were relatively high in total potash except a few sandy samples. These various results were shown to correspond roughly with crop response to lime and fertilizer in the state, but emphasis was placed upon the limitations of the information presented. It was pointed out that various soil differerces were seen within particular soll types as mapped in the field, that total chemical analyses were obviously inadequate to judge the immediate availability of soil nutrients, that limiting factors such as soil drainage were not evaluated, and that many problems of fertility would recessarily require field, plot experimentation for their solution. In recent years the progress of agronomic science has thoroughly demonstrated the necessity for considering the various factors indicated.

Progressive change in the fleld mapping of soils has rlaced greater emphasis upon the soll itself and less on tre material from which it was derived. The degree of erosion has gained recognition along with the other soll features, and greater detall allows for more soil separations. Consequently the recent surveys provide much more information. They represent a challenge to find out what the separations mean in terms of approved laboratory procenures an तo so1l-management practices.

In 1937 a bulletin was published concerning the systematic grouping of West Virfiria land into classes based on use and agricultural value (36). It brought together all of the availatle information regarding solls, slopes, erosion, stoniness, climate, etc. into a general classification. The grouping:s are necessarily generalized because of lack of detailed information as well as limitations of scale, and, although the classes as shown have many uses, the author has indicated the need for further information about the soils and otrer limiting factors. As additional field and laboratory results become available, it is to be expected that refinements will become possible in any such classification, and there is always the hope that new developments will show the way to overcome apparent limitations "rith consequent shifting of land classes.

\section{FIEID SAMIING AND DESCRIPTIONS}

It sems neither necessa 'y no wise tc follow a rifid 
system of soll sampling and description in this study. Some semples must be collected with particular objectives in mind, whereas others are taken for more complete analysis and general comparison. Most profile samples are taken from all clearly defined horizons of a particular soll profile, and an attempt is made to record all pertinent information. Some of the results reported, however, were obtalned by sampling only the surface soll or some particular horizon within the soil profile.

Sites are selected to represent various soll types as we know them, and detalled descriptions are taken 80 that there will be a minimum of confusion as to whether the soll typifies the type or belongs in some new subdivision of mapping. Whatever the situation, the notes w111 permit relocation of the site and are detalled enough to enable a field speciallst to form an oplnion as to the soll represented.

Most samples are collected from untreated soils, but treated samples may be taken if the history $1 \mathrm{~s}$ known. In taking profile samples, the total depth has been governed by one of two things. If a structural B horizon is evident, samples are taken through this and into the apparent $C$ horizon. If no $B$ horizon is recognizable, the sampling is carried down unt1l parent rock predominates or interferes. Compared to soil-profile sampling in various other states, it is evident that the average depth will be less in Mest Virginia because of the relatively shallow thickness of the soll mantle in many places.

It has not seemed practical to subdivide surface or subsoils into very thin leyers in all sampling, but in order to determine certain detalls regarding the distribution of organlc matter within surfece soils in pastures, a number of determinations were made with samples of $1 \frac{1}{2}-1$ nch depths. other surface solls have been subdivided only insofar as distinct differences were evident which would normally be considered as justification for recognizing an $\mathrm{A}_{0}$ or $\mathrm{A}_{2}$ as well as an $A_{1}$ horlzon.

\section{LABORATORY METHODS}

All chemical data reported are for air-dry samples put through a $2 \mathrm{~mm}$. sieve, except $\mathrm{pH}$, which is determined before the soil reaches air dryness, and ercept organic matter, whlch is determined on dry material ground to pass a 60-mesh screen. Gravel contents ( $>2 \mathrm{~mm}$ ) would affect the calculation of results to an important extent in certain cases, but 
this factor is neglected unless specifically mentioned.

\section{TEXTURE}

Mechanical analyses in the laboratory have been made by the pipette method with sodium oxalate as a dispersing, agent and a 15 minutes' stirring in a drink-mixing machine (37). This method has seemed effective in dispersing the various semples studied.

\section{SOIL STRUCTURE}

Dispersion measurements have been made essentially as described by Middleton (29). Pore-size distribution was determined as previously described by the authors (45). Evacuation of samples before wetting is used as standard procedure in accordance with the suggestion made in the above reference that prior evacuation prevents physical disruption of natural samples, thus giving a more accurate plcture of the true poresize distribution. As an index of the fine-pore content and water-holding capacity, moisture equivalents have been determined by the Gooch crucible method ( 9 ).

Field and laboratory observation supplied much of the present information about soll structure which no known methods are designed to measure.

\section{Organic Matter}

Organic matter was determined by the method of Walkeley and Black as modified by Browning ( 8 ). This determination seems to give accurate relative values for surface solls unless unusual quantities of fresh organic matter are present. In that case it is probably unreliable (44), but few if any of such samples are involved in the present results.

With subsolls, data have been published (32) showing that there are wide differences in the ease of oxidation of the organic matter, but it would seem that the relative values for oxidizable material might be reasonably satisfactory. Results in this laboratory cast considerable doubt upon the validity of lower subsoll comparisons by this method. There is apparently some factor other than organic matter which sometimes introduces unreasonable fluctuations in the values obtained for similar subsoll horizons. These wide variations are usually obvious, but they seem unpredictable and lend doubt to the use of lower subsoil values in any except the most general types of comparisons. 
Soll reaction, expressed as $p H$, is measured with the glass electrode in a $1-2 \frac{1}{2}$ soil/water suspension. Fresh field-moist soll was used in most cases with 24-hour sosking in water before the determination. Varlations from this procedure are noted. Dried and stored samples have invariably showed a decrease in $\mathrm{pH}$ which is only partially reversible by soaking. Greatest differences are with h1. ô-base subsoils or limed surface solls. Samples collected in summer or early fall have somewhat lower pP values than those collected in the winter or spring.

\section{Buffer Curves}

These are obtained by adding base to a $1-2 \frac{1}{2}$ suspension of the soil in water and determining the pH after essential equilibrium has become established. $\mathrm{Ba}(\mathrm{OH})_{2}$ and $\mathrm{Ca}(\mathrm{OH})_{2}$ gave the same results for a number of samples; hence $\mathrm{Ba}(\mathrm{OH}) 2$ is used because of its higher solubility. Two-day contact has been found necessary for essential equilibrium. For convenient reference to fleld liming as well as for comparison with results of the next method to be described, pH ? is considered as essential saturation with bases, although it is recognized that higher $\mathrm{pH}$ values are required for saturation from any theoretical point of view. There seems to be no practical gain by accepting a theoretical saturation point well above the aim of all field-liming programs. In the same way that Plerre defined lime requirement relative to the desired $\mathrm{pH}(33)$, so for the present purposes all base-saturation comparisons refer to saturation at pH 7 .

\section{Exchangeable Bases and Exchange Capacity}

These have been determined for most samples by a sligit modification of the widely used neutral, normal, ammoniumacetate method (6). In addition, bases have been determined by the Kappen acid-equilibrium method (21), and in some cases exchange capacity has been obtained from buffer curves as described above. The method used will be indicated in connection with the data.

A comparison of the methods mentioned for determining bases has shown \& fairly satisfactory correlation between the two, although the Kappen method gives consistently higher results and the differences tend to be greater with shaly samples than with highly leached terraces or sandy uplands. 
This apparently indicates a certain degree of action by the acid upon the unweathered minerals of the shale, whereas with the terraces and sands there are almost no fresh minerals except quartz, which has no basic properties.

\section{Soluble Phosphorus}

All determinations have been made by the well-known Truog method (48).

\section{Exchangeable Potash}

Potassium has been determined on an aliquot of the neutral, normal, acetate leachate by the method described by Brown et al. (7).

SOII-PIROFILE PROPERTIES

\section{Soll Color}

It is obvious that individuals may vary widely in their descriptions of color, and color standards, therefore, offer a considerable advantage. Some difficulty has been encountered in matching against the standards used (39), but this is ordinarily not serious. Certain standards which are lacking, notably greyish brown, would seem likely to match many surface soils better than the brownish greys given. The standards invarlably recognize less red in a number of solls than is described by most people, but this may be justified, since solls of certain other areas undoubtedly show more real shades of red than are characteristic of West Virginia. The Hagerstown subsoll, for instance, is often described as reddish brown or even as red by some paople, whereas the standards seem to indicate a bright brown or dark orange. Another example is the Upshur, which seems red to most people but is light brown or, in some locations, weak or light reddish brown by the chart. Calvin soil is also considered red, and in the case the chart is more in agreement, the most common chart desionation being dusky red. Some horizons, however, match certain shades of brown.

These apparently represent the widest divergencies between ordinary local opinions and the color standards. By using the standards as the basis for all soil descriptions these local opinions are probably unimportant.

In any interpretation of soil colors in West Virginia, 
It is obvious that inherited colors should be distinguished from developed colors insofar as possible. Most of the uplands show strong inherited colors which are nothing more than the color of the parent rock carried over into the soll. Examples are the Upshur and Calvin, which are derived from red shales. Many of the other shallow upland soils could be cited as well. Such colors may be significant if they are associated with parent rocks having certain specific chemical or physical properties, but in many cases it is believed that these inherited colors have little meaning in terms of characteristics which influence the nature or fertility of the soil. If true, this is unfortunate, since inherited color is a relatively clear-cut characteristic which is likely to be accepted as the basis for soil-type distinctions in preference to other less obvious properties which may have some fundamental significance. For example, there would probably be a strong tendency to group reddish acidshale solls into the Calvin serles, although variations in the depth and development of the soll profile or in base content on such shale might be very great. A ture soil with distinct $B$ horizon would sometimes be seen, whereas in other cases the soil would be little more than a thin mantle of weathered soil material with slight organic-matter enrichment overlying the parent rock. The deep soll would be recognized as a different series if it were well defined, but color would probably overshadow depth unless the surveyor was especially alert. This mieht lead to a lumping of fundamentally different soil profiles on the basis of the superficial similarity in color, although it would be unlikely that the color would be an important characteristic, either pedologically or practically, whereas soil depth and horizon development are of recognized significance. Similarly, variations in base content might be large and important, but inherited color would tend to determine the soil separation.

The authors realize that such detailed difficulties as described could be found within practically any soil type mapped anywhere, because of the impossibility of making all the minute distinctions which occur in nature. The illustration is used to indicate that a factor such as soll color cannot be expected to provide a sound basis for use of the land, because inherited colors are not fundamentally important and are likely to obscure less obvious soll characteristics which do determine the capacity and use of the land.

Developed soil colors are not always easy to distinguish from inherited colors and are not always simple to in- 
terpret, but ordinarily they seem to promise more neaning. The pale yellow and grey of the Monongahela and Cuskport series are obviously a result of development and suggest leached, erosible, infertile soil. The unfform reddish brown (strong brown or dark orange by the color chart) of the Hagerstown has developed and seems indicative of a wellaggregated soil with high fertility. The pele grey, mottled with rust brown in the subsoll of Tyler, Pur iy, Atkins, and Blago, has developed and apparently indicates a generally high but fluctuating water level with reducing conditions predominant most of the year. With Blago the high water level is probably more consistent than with the lighter colored soils mentioned.

In surface soils the organic-matter content tends to dominate other coloring agents, giving the gradation from light to dark which is often accepted in soll groupings. Generally throughout West Virginia a surface soil is rated as dark if it has more than about 4 percent of organic matter. The average upland is a loam or a silt loam in texture, and this influences the amount of organic matter recuired to give a certain degree of darkness. Clays are not likely to be considered dark unless the organic-matter content is 5 percent or more, whereas sandy loams appear dark with 3 percent or even less.

This discussion is intended to draw attention to the factor of soll color, which is being considered in the present studies. Certain color differences will be mentioned in connection with other soll factors and with laboratory measurements. It is hoped that accumulated data and experience may add significance to the various color distinctions, but there is at present little known proof of the importance of particular colors in West Virginia solls.

\section{Depth axd Gravel content of the Soil Mantle}

In West Virginia, where upland soils are ordinarily rather shallow, the total depth of unconsolidated material over the solid rock is one of the most important factors determining the ultimate use of the land, particularly its use for any deep-rooted crops.

The depth of soil material represents a balance between rock weathering and natural or accelerated erosion. Aside from bottomland and terrace soils deposited by stream action, there is a tendency for the deeper mentles of up- 
land material to accumulate on the lower part of slopes. Here it is recognized as colluvium and is distingulshed from the adjacent uplend in detalled soll mapping. These deep colluvial soils are potentially among the most productive soils of the state. Often they are suited to more intensive croppling than the adjacent upland. Solid rock is often covered by six feet or more of soil material containing only minor quantities of shale and stone. This material is normally deepest on the lower part of slopes and thins upward toward the ridge tops. Where there is no colluvial influence, uplend shale soils are normally only 20 to 30 inches in total depth.

It is difficult to estimate the acreage of deep colluv1al soils because their occurrence is a matter of degree, and their contacts with the residual upland are poorly defired. It seems, however, that colluvial solls with bedrock burled deeper than 3 to $3 \frac{1}{2}$ feet are mach more abundant than is commonly belleved. Various instances are known where this depth of material extends at least half way to the top of long slopes, reclining on slopes of 30 percent or more. There are also considerable areas of such solls on rock or old erosion terraces at various levels above the valleys, separated by shallow soils derived in place. It is difficult or impossible to separate all such areas from the ordinary upland even in detalled mapning, but full attention would seem justified in detalled farm planning because of the urgent need for productive crop land on most West Virginia farms.

The coljurial benches should not be confused with the high acid terraces derived from old allurium and often found in similar dositions. True colluvial solls are less strongly leached, darker colored, have better structure, and have no subsoll "pans" like many of the alluvial terraces. They are most readily recognized by their content of unsorted, angular rock fropments. Colluvial soils are as fertile as the bordering upland and are invariably more productive because of their greater depth, whereas alluvial terraces are ordinarily less fertile and more limited in their productive capacity.

Studies of numerous cores near Morgantown (17) in Monongalia County have reverled some of the deeper profile characteristics and water relations of colluvial soil of this area (17). Relatively strong leaching of bases has occurred to depths of about four feet, below whin the $\mathrm{pH}$ and the base content increase. This increase in $\mathrm{pH}$ and bases 
seems associated with increased mottling and increased clay content. The layer above four feet up to within about 20 to 30 inches of the surface is strongly acid ( $\mathrm{pH} 4.8$ to 5.0 ) and quite silty $(17,18)$. It apparently corresponds with the $Y$ horizon, which has been described in otber areas $(13,50)$, occurring below the structural B horizon. The silty horizon has low coherence and is corsidered as the main zone of weakness and morement in soil slips of this area (18). Recognition of this horizon in the field can probably be used as a criterion of the danger of soll slipping. If tile drains are placed in such soll, they should probably be located at the base of this leached, silty layer to assure that none of this material can become supersaturated and start to flow down the slope. The failure of some tile or ditch drains probably has resulted from improper depth placement in such soils.

There is considerable information about the depth of upland soil profiles in the Eastern Panhandle (11) and about the importance of this factor to the orchard industry. Probably not enough attention has been given to soil depth throughout the remainder of the state, particularly in connection with the growth of alfalfa, fruit and forest trees, and to some extent, corn. On many of the shaly uplands the soll material has been found to contain 50 percent or more of gravel within 18 to 24 inches of the soll surface, with firmly berded shale or sandstone at 36 inches or less. In extreme cases, of course, the shale predominates up to the immediate surface, but the depths and the gravel content listed are quite general in the true Gilpin, DeKalb, Calvir, and other major upland solls.

A certain amount of gravel dispersed through a soil profile is probably beneficlal in maintaining permeability and preventing erosion, but when the content of coarse material exceeds about 50 percent of the total soll weight in the main plant-root zone, it is believed that the crop is likely to suffer very seriously. With alfalfa or apple trees a depth of three feet to firmly beeded shale is obviously insufficlent for best results. With corn, gravel contents approaching 50 percent within the 12 to $18-1$ inch depth are belleved likely to be seriously limiting to growth. Corn roots seldom extend much below 18 inches in this region.

W1 th grasses and white clover on pasture plots in Greenbrier County, the growth and response to treatment has seemed little influenced by a measured gravel content of 
10 to 20 percent, but stunted growth, drouth damage, lack of clover, and persistence of inferior grasses has been evident where the gravel content is 50 to 60 percent of the surface soil. This gravel is mainly chert or flint and practically nonporous.

Much more study is needed to determine the full significance of gravel content as well as of total soil depth. The above suggestions are offered on the basis of a number of measurements of gravel proportions in the soil and a varlety of observations as to root relations and crop success. It is hoped that further information will permit more specific suggestions as present studies are continued. In any final analysis the nature of the gravel must undoubtedly be considered as well as the total amount, because the porosity and other properties of gravel are quite varlable.

\section{Soll Textures}

This soll factor can be evaluated in the field within moderate lifits, but it is important to have laboratory data as a check on field evaluation. It is not considered essential at present to make mechanical analyses of all the soil materials sampled but rather to have a body of representative results accumulated for reference and to make occasional analyses of new samples for specific purposes. Considerable data have been obtained, and it is felt that these serve the initial purpose, although other mechanical separations will be required from time to time, especially in connection with soil structure or aggregation studies.

The important role of mechanical composition of soils is obvious since texture is related to practically all of the fundamental physical and chemical properties. It is not the particle size alone, however, but also the mineralogical make-up which governs the various reactions of the mineral fraction of soils.

Mechanical analyses of 18 complete profiles indicate that 8 surface soils are silt loams, 8 are loams, 1 is a clay loam, and 1 is a clay. If we average the various horizons of the corresponding subsolls, the results show 12 clays 4 clay loams, 1 silt losm, and 1 loam. Since 7 of the silt loam profiles are from limestone areas, it is believed that these textures average heavier than the general uplands. Most of the shaly uplands are apparently loams or shaly loams, and many of the subsolls are gravelly clay loams by 
laboratory measures. They contain more sand and gravel than silt loams and are generally less erodible on that account.

The data on mechanical analysis, particularly the clay contents, will be discussed further in connection with other soll measurements.

\section{Soll Structure}

Soll structure may be defined as the arrangement of soil particles, whether as individual or as comnound units. In general, structure should be considered as a fundamental soil property rather than as a property imposed by man; but on land that has been converted to various uses, the present particle arrangement, at least in the surface soll, is almost certain to reflect the use to a considerable extent. Even so, the fundamental nature of the soil evidenced by natural structure is not easily overcome, and it is to be expected that many structural distinctions can be drawn along soll lines regardless of use. Differences due to use may be segregated independently of soil type in other cases.

Soll structure is being studied by detailed observation, by aggregation and dispersion measurements, and by moisturetension determinations which indicate effective pore-size distribution. All three of these approaches have yielded certain information, but there is always considerable difficulty in interpreting the information obtained. Wuch work remains to be done toward perfection of the relation of various structural indices to practical conservation and production problems; but even with present knowledge, structure can often be used as an index of soll fertility or productive capacity as well as of permeability to water and plant roots. It is not always the structure itself which is important, but the other soil properties known to be associated with a particular structural type.

The structure of loam, silt-loam, and sandy-loam surface soils in West Virginia pastures and cultivated land is largely a matter of degree, that is, the degree of aggregation of the primary soil particles into units of sand size or larger. With silty, sandy, or loamy soils these surface aggregates are normally quite porous, conforming with definitions of granules $(4,22,24)$. If silt loams, sandy loams, or loams are strongly aggregated, the structure is ordinarily favorable for high water intake, resistance to erosion, easy tillage, good aeration, and high crop yields. Conversely, weak ag- 
gregation, or a tendency toward single-grained structure, is unfavorable in all the ways mentioned. This is more true of silt loams than of sandy loams, since the primary particles of sand are large enough to allow more favorable conditions than silt. But even with sandy loam, surface aggregation is 1 mportant. It not only assures an adequate supply of coarse pores for rapid water intake but also tends to provide a higher water-holding capacity.

The main binding agents for surface silts and sands are humus and fibrous roots, whereas with clays there is an inherent capacity for aggregation that varies with the amount and the type of the clay (4). In West Virginia, clay aggregates are typically angular and cormact. Tillage of clay or silty clay surfaces ordinarily involves considerable difeiculty, because the soll is too sticky when wet and too cloddy when iry, with only a very limited range of molsture conditions sultable for working the ground. Flbrous roots and abundant organic matter of the proper kind tend to eliminate the sharp-angled gacregates and clods and to lend permeability to the structural units, but even large quantities of organic matter may orly partially eliminate the difficulties. Organic matter that is actively decomposing offers more promise than inert material (10), and surface mulches are effective in promoting an improved physical structure, but many problems remain unsolved in the use of clay surface soils.

Soil aggregation is difficult to evaluate with certainty in the laboratory, but useful relative indices are obtained by any one of several methods $(29,51)$. Middleton's dispersion ratio and its modifications have proved rather satisfactory in estimating the relative erodibility of solls when all external factors are kept constant (29).

In West Virginia this measurement has been apclied to a number of soil profiles. The results have been rather variable within soll types or apparently similar horizons, but certain characteristic differences are obtained. According to the standard suggested by Widdleton (29), most West V1reinia soils are quite erodible, showing a higher dispersion ratio than 15 percent. Aggregated clays show ratios as low as 20 percent; leached sandy and silty materials have ratlos from 75 percent to 100 percent. Data by Browning and Sudds (11) show similarly high dispersion ratios. Soll dispersion naturally cannot take into account such a factor as gravel con- 
tent, which affords considerable protection agiinst erosion in many upland solls (26). Subsoil permeability, too, is rather high on the average in West Virginia, affording another factor opposed to excessive erosion. Considering these and possibly other soll factors, and the fact that rainfall is not ordinarily of the torrential type, it would seem that the borderline between erodible and non-erodible soils mifht be set at a somewhat higher value than 15 percent on the average. Otherwise the other soil and external factors should be given greater relative consideration. From observations, it is suggested that for the high, silty, and loamy terraces, for the yellow and grey silty limestone solls of the Fastern Panhandle and of the Greenbrier Valley (Plckaway, Frankstown, and Frederick silt loams), Por the silty uplands of the southern Ohio River area, and for the silty ridge-top solls of most of the shale upland areas, the high dispersion ratio gives a correct indication of high erodibility. But for a large part of the sloping uplands over the rest of the state, the shale content and the subsoil permeability prevent the soils from being classed as highly erodible. With other uplands (Testmoreland, Meigs, Upshur, Cavode) the dispersion ratios are not so high, but the solls are often highly erodible because of slowly permeable clay layers close to the surface. In any case, erosion control in West Virginis is recognized as primarily a matter of keeplng the soil covered with vigorous, close-growing vegetation most of the time, so that soil factors governing crop growth are often more significant than such a factor as ease of dispersion. When tillage is planned, however, the soll factors discussed are important. Good surface aggregation, high gravel content, and deep, permeable subsolis all contribute to the control of mun-off and erosion. Slope is often a less important factor than these soil characteristics in determining run-ofe and erosion, as can be seen from the severe erosion losses on many cultivated fields with slopes of 5 percent or less. Solls that are naturally erodible cannot be heavily cropped without destructive erosion even on gentle slopes. This fact is sometimes overlooked in a state like West Virginia, where most of the land is so steep that cultivation is difficult except on the few gently sloping areas.

\section{Structural Profiles of Solis}

On cultivated land the intake of water is probably related more closely to the condition of the immediate surface 
than to subsoil structure (15). With grass or timber cover, subsoll permeability is ordinarily the limiting factor (16), and by studying entire profiles it is possible to associate certain structural characteristics with types and degrees of soll development which help to reveal the permeability as well as other properties of the soll. In general, it seems possible to refer most of the soils in West Virginia to a relatively few main types of structural profiles as standards. These standards may represent particular soll types, or they may serve as a basis for reference and contrast of various soll features as we know them. They should be considered not as an attempted accurate portrayal but rather as 1llustrative and schematic, to assist in orienting our concepts of structure.

Figure 1 illustrates a structural profile that is typical of terrace solls developed from slack-water clays. It shows rather strongly developed, large, moderately porous aggregates in the surface where organic matter is abundant. At 5 to 10 inches these units glve way to more angular aggregetes, or fragments, which are relatively low in organic matter and only slowly permeable. The well-defined cleavage plane st1ll afford abundant space for water movement. Gradually these fragments incresse in size, becoming what might be termed blocks. They often tend toward a prismatic shape, althourh in some cases the horizontal and vertical dimensions are essentially equal. At 15 to 20 inches, the blocks, or prisms, have normally reached a diameter of an inch or more, and it is believed that the fully swollen material permits very little water movement. Below this depth the clay blocks become larger, approaching a massive structure in which water movement is inslgnificant ( $<0.002$ inches per hour). The 5 to 10-inch layer, if not the surface itself, ordinarily shows grey and brown mottling indicative of water saturation and lack of aeration during much of the year. Occasionally the mottling is absent to somewhat greater depths.

The structural profile described is also rather typical of heavy upland soils developed from clay shales or fire clay, except that horizontal bedding instead of the massive clay becomes evident in the lower subsoll. The permeability is not much different, and the fundamental physical properties are apparently similar. One difference is that on the normal rolling or hilly upland, the surface water may drain down the slope on top of the impervious layer, so that little or no reduction and mottling are evident. This type of drainage requires a ratier coarse, stable surface structure to afford 


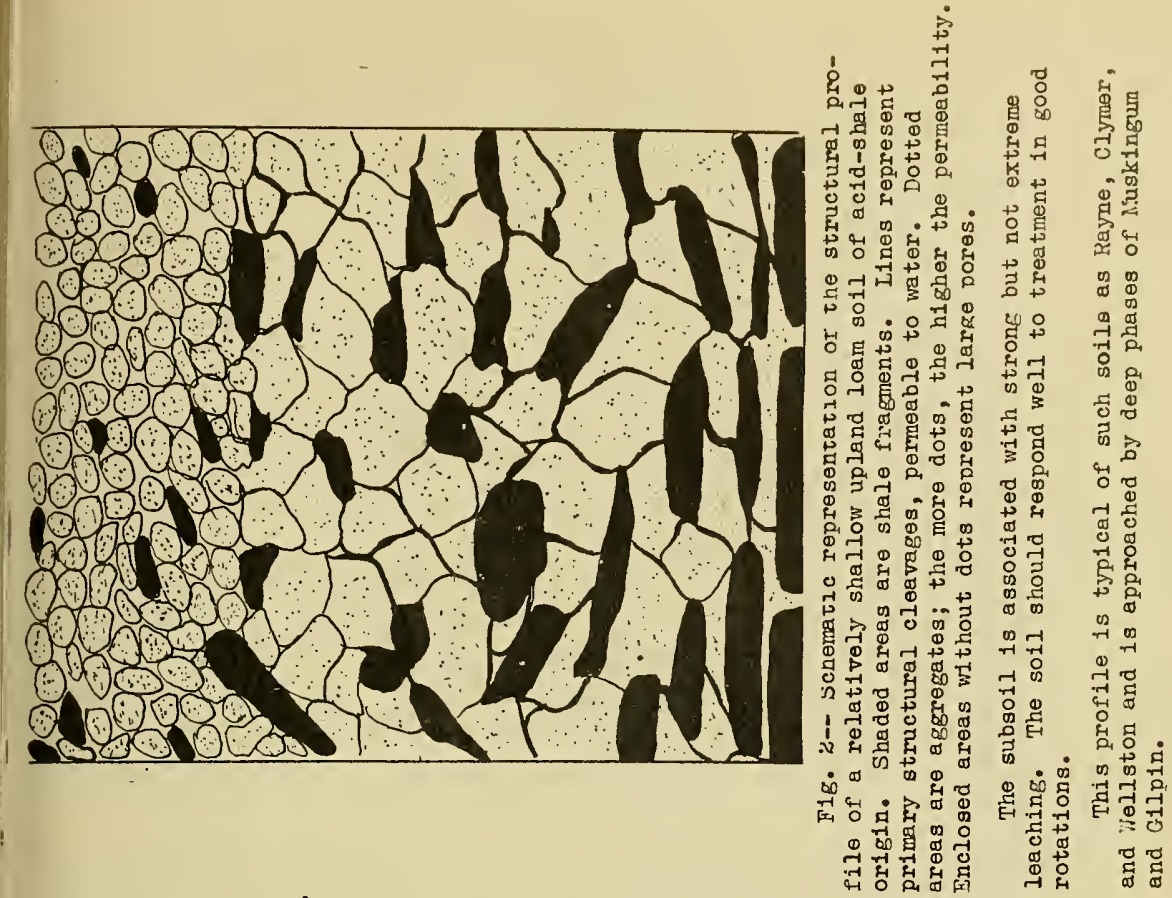

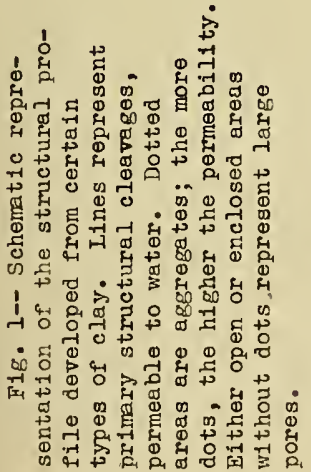

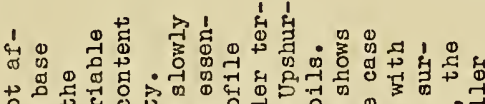

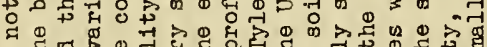

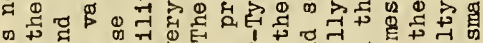
व 0 क

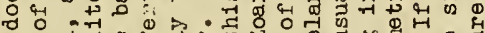
ه न 落

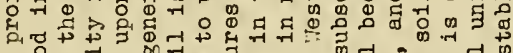
o : $\begin{aligned} & 5-1 \\ & 5\end{aligned}$

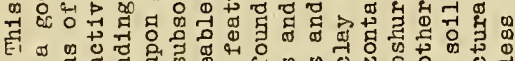

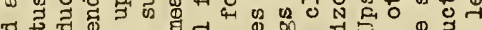

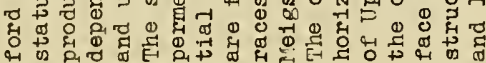

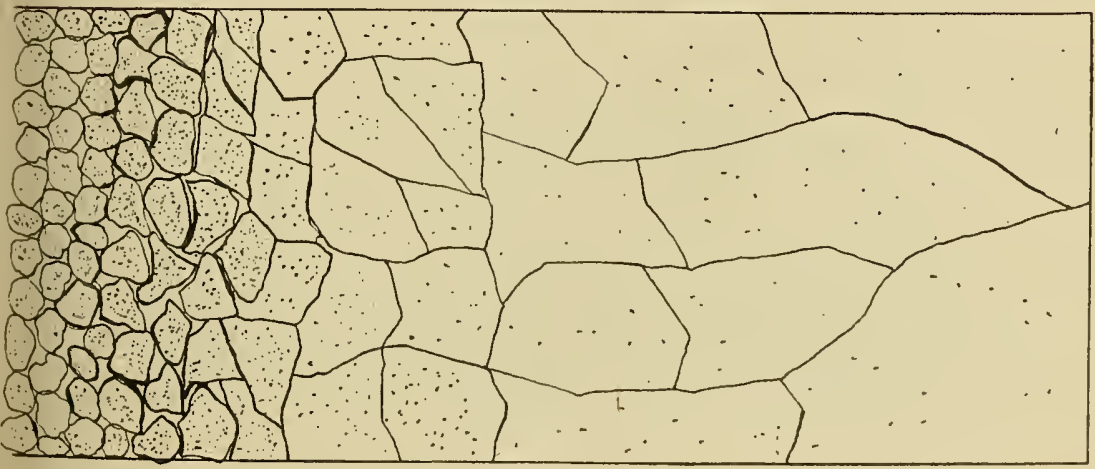


large pores which will drain under low tension. Poorly aggregated clays and silty, single-greined layers over clay ordinarily hold water to the extent that definite mottling and "buckshot" are evident even on steep slopes. Highly silty surface layers probably do not develop from the clay-shale on upland slopes in West Virginie, but the condition is fairly common because of the alternation of clay-shale and siltshale horizons in the perent rocks. These solls are mapped as Cavide and Wharton. Some Upshur and Brooke may develop structural profiles similar to that shown in Figure 1. Most of these solls will be mapped within the Meigs and Westmoreland soil complexes rather than as distinct types; all gradations into Gilpin are found. Many soils, both on the clay and silty shales, are too shallow to show much of a structural profile, but the structural gradation from rounded, stable granules to impervious clay is typical when the soll has developed from the clay. If lime is abundant in these subsoils, the structural units tend to be smaller and the permeability higher, resulting in a structural profile more like Figure 3, which will be discussed later. This is especially true of Brooke solls.

Flgure 2 represents the bulk of the shallow shale uplands which are deep enough or have remalned in place long enough to show a characteristic structure not governed by the parent shale. Permeability and aeration of the subsoll are favorable for water movement and root development. The subsoll structure is only weakly dereloped where the soll is shellow or is subject to frequent movement. In such cases the size, shape, and distribution of the shale and other stone fragments have a strong influence upon the normal physical constitution, and the true aggregates are more varlable in size and shape, being mainly smaller and less well defined thar the typical subsoil units shown in the Figure 2 profile. The frequent soll movement and the stone fragments ordinarily provide abundant looseness and aeration for plant roots.

The structurel profile type shown in Figure 3 is drawn from studies of the Hagerstown series. It is extraordinarily favorable for air and water movement and root penetration. The surface aggregates are well-developed granules of favorable size and porosity. Below the surface 8 to 12 inches the aggregates become somewhet more angular and less porous; but they fit together loosely, leaving about the same volume of pores among the aggregates as characterizes the surface. There are no distinct horizon boundaries; all structural changes are very gradual. The aggregates become moderately 
angular and tend to become larger and somewhat more closely packed with depth, but in the typical Hagerstown soll these changes are sirall. The subsoll clay is quite strongly eractured to indefinite depths depending on the distance to the parent limestone. In certain cases, especially where free carbonates are abundant, the lower materlal may apperr even more thoroughly fractured than the middle subsoil at the 15 to 25-inch depths. It is believed, however, that the more characteristic condition is the gradual change with depth shown.

Thls soil seems favorable not only in appearance but in production of deep-rooted crops. Apple-tree roots have been shown to follow the structural cleavages to great depth (11), and the same deep penetration by alfalfa roots has been observed. The avaliable water supply is large. There seems to be little reason to question the importance of this structure but it should be remembered that the Hagerstown and like subsoils not only have a favorable structure, but they show a favoreble pH and saturation and abundant bases, and in some cases they may carry considerable available phosphorus. (See appropriate passages in the text.) It is difficult to say, therefore, that structure is the only or even the main reason for the deep root development. The fertility factors may bo of equal importance. Or at least these various properties are all very closely interrelated and difficult to isolate.

Structural profiles of Figures 4 and 5 are apparently indicative of very strong leaching, low fertility, and high erodibility. They are known as "siltpan" or "hardpan" solls. A laminated pan is shown in Figure 4, the fully-developed, massive pan in Figure 5. The type in Figure 4 seems to derelop only in silty raterial with few stones. It is typical of the Pickaway-Frankstown solls in the Greenbrier Valley. The real Frankstown as described has none of this development but much of the gently rolling area of the yellow-grey limestone soils of the area shows strong lamination in the lower subsoil corresponding with the appearance of some grey, yellow, and brown mottling. Similar, strongly laminated subsoll layers occur on the acid-shale uplands, where the soil is quite silty. These heve been observed in both the cookport and the Tilsit silt loams, although these types may have more massive pane as in Figure 5. The laminated pan should not be confused with the fine flakes found in silty surface or subsurface layers. The subsoil laminations are firm and somewhat harsh and vary in thlckness from about $1 / 8$ to 1 inch. This type of subsoil is not so compact as the wassive pan, but it apparently represents an impediment to root developmen 


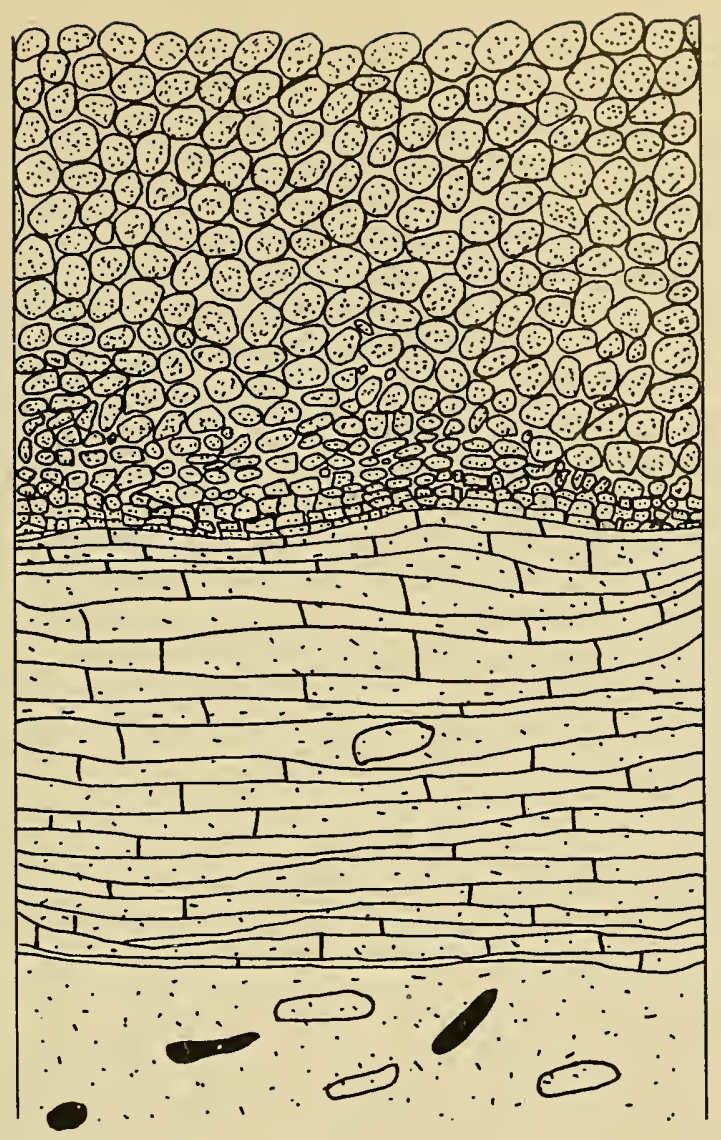

Fig. 4-- Schematic representation of the structural profile of a strongly leached silty soti.

The surface structure is not favorable for rapid water intake or for resistance to erosion. The laminated subsoil is only slowly permeable to water, but under cultivation the surface condition is normally limiting to infiltration.

This profile is associated with rather low fertility but moderate to good response to treatment. Erosion is likely to be severe under cultivation. Special precautions are needed to maintain organic matter and otherwise to protect the surface from rainfall and run-off.

Low subsoil fertility is likely to limt the success of alfalfa.

This profile is found in Frankstown-Plckaway areas in the Greenbrier and in better phases of Cookport, Tilsit, and lionongahela silt loams. 
and is associated with a h1ghly leached soll. This horizon is shown underlain by pervious silty materlal, which has been the case where it has been studied. The porous units in this layer are intended to represent the light-welght silt-stone or Pine-sandstone fragments of the Frankstown-Pickaway or the permeable sandstone in the Tilsit and cookport. It is believed that the high natural perviousness of this type of material delays or even prevents the development of the massive pan.

With the type shown in Flgure 5 the pan, showing characteristically encased pores or small pockets of pores, overlies a clay. This is not an essential feature, but some of the most strongly developed pans occupy such a position, and this natural impediment, if present, is belleved to hasten and intensify the typical pen formation. In such a case, there would seem to be little hope of ever improving the natural subsoil permeability, whereas with the laminated pan underlain by poraus material, subsolling or pan-breaking might offer some promise. It should be especially noted, however, that such physical development seems consistently associated with low fertility (see passages on acidity, bases, and potash), so that pan-breaking alone would seem to promise little reward at best. Deep placement of lime and fertilizer might be more beneficial than physical disruption of the pan.

In experiments with alfalfa at Morgantown, deep rilacement of lime and fertilizers resulted in a marked increase in deep root development, although the physical condition of the soll was uniform throughout. This suggests that the low fert1lity of pans may prevent root development regardless of the physical compaction.

Another feature of Figures 4 and 5 , as shown, is the smaller surface aggregates, which decrease in size down to the pan horizon. This seems characteristic and causes these solls to be highly erodible, although the structure of the immediate surface may be influenced considerably by use. The subsurface lajer contains mainly small sand or silt-sized units which sometimes approach the single gralned type of structure. This rather floury layer probably permits only relatively slow water movement regardiess of the lower subsoll.

There are various intermediate stages between the permeable subsoll shown in Figure 2 and the massive pan. In the case of much eravel, as shown in Figure 2, and also in sandy or loamy soil material there is little likelihood of the lam- 


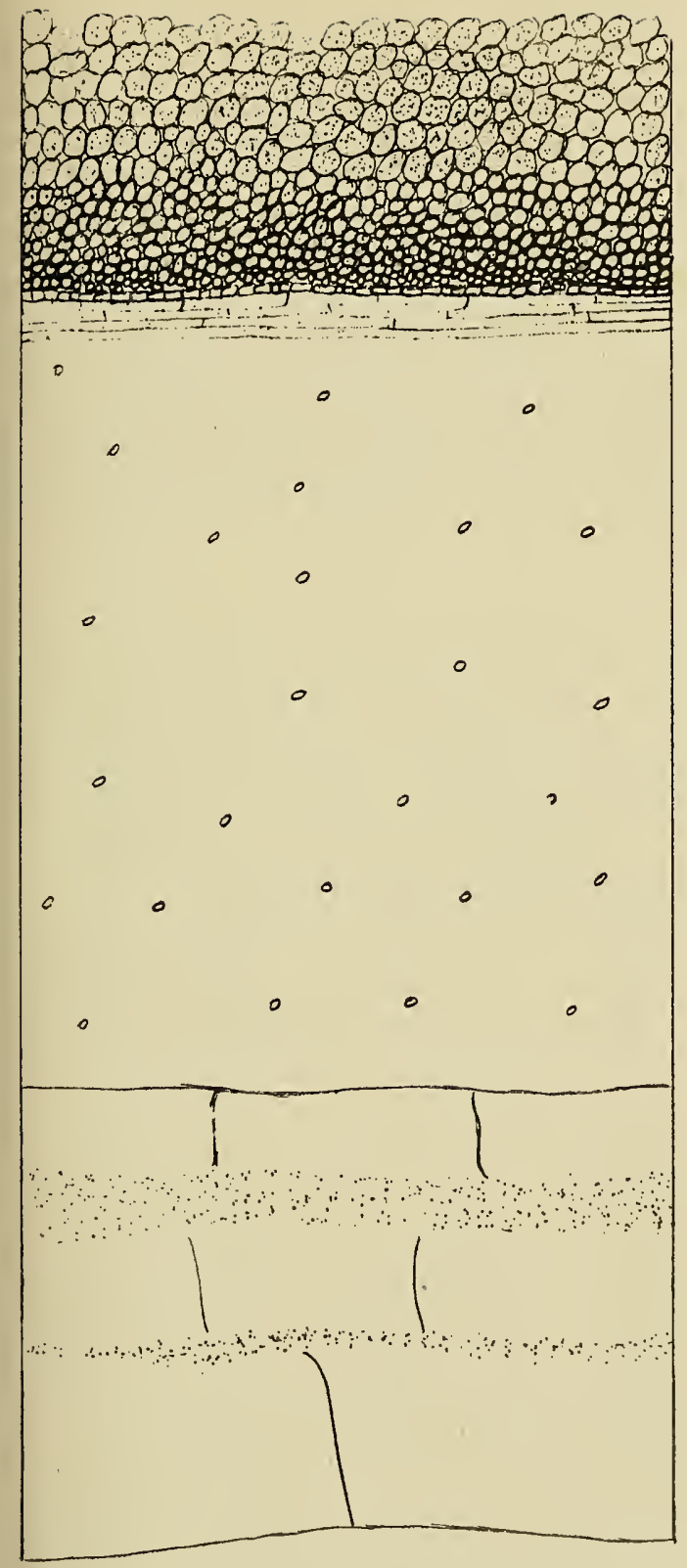

Fig. 5-- Schemetic representation of the structural propile of a very strongly leached silty or fine sandy soil with a subsoil "silica pan."

This profile is associated with all of the undesirable features of Fig. 4, intensified, and is less responsive to treatment. It occurs mainly on slopes of 5 percent or less, but is very erosive under cultivation even on gentle slopes. This soil requires the protection of close-growing vegetation most of the time. It is unsuited to alfalfa and not well suited to corn.

lonongahela terraces and Cookport or Tilsit ridgetons typify the essential features shown. The clay-sand substrata are found on terraces; shale parent material occurs on the uplands. 
Inated stage as shown for silty profiles. The intermediate stages apparently are characterized by the coalescing of the normal nutlike aggregates into less distinct and more compact units. This is accompanied by the appearance of some brown, grey, and yellow mottling and can serve as an index of strong leaching. Much of the Rayne silt loam as mapped in West Virginia seems to typify this condition, grading into cookport as the pan and mottling become pronounced. The pan seems to reach its maximum development immediately above the parent shale in these solls. The mottling apparently is largely a matter of strong but variable leaching of iron. This seems con. firmed by the pale coloring, lack of iron concretions, strong acidity, and low base content of all such pans as well as by microscopic observations which reveal that much of the greyness is apparently from fine grains of clean quartz. The term "silica pan" seems appropriate for these horizons $(25,31,50)$.

\section{Surmary of Soil Structure}

Detalled observations of the structural condition of surface soils and subsoils can often serve as an index to soil permeability, erodibility, productivity, and general capacity for use. The size, shape, internal permeability, and hardness of the natural units into which a moist soli crumbles upon handing are the most important factors to consider in studying soil structure. Aggregates from crumb to small nut size are ordinarily most desimble in West Virginia soils. Pounded, porous agcregates are more desirable in surface solls than angular or blocky units. Visible porosity of the aggregates is associated with the more favorable structural types in surface soils but is not so essential in subsoils. Porous surface agkregates should be moderately firm and should not collapse into silt under pressure or water action. They should feel somewhat spongy or elastic. Very large argregates in surface or subsoil ordinarily mean a tendency toward massiveness, which is unfavorable. Massive structure in surface soils suggests cloddiness, puddling, and poor seedbeds. Very small aggregates often indicate a tendency toward sinelecrained structure, which is also unfavorable. Surface crusting, high run-off, and severe erosion are characteristics of solls with small aggregates or single-grained structure.

Subsoil pan layers indicate strong leaching and low fertility as well as high erodibility. Thoroughly fractured or fragmented clays indicate a high lime content. Blocky or massive clays are not necessar1ly related to any particular lime status, but the structure indicates low permeability and slow dreinage. Well-formed, nutlike (sub-anqular) subsoll units are found in meture upland soils of this repion. Such soils 
ORGANIC MATTER

PERCENT
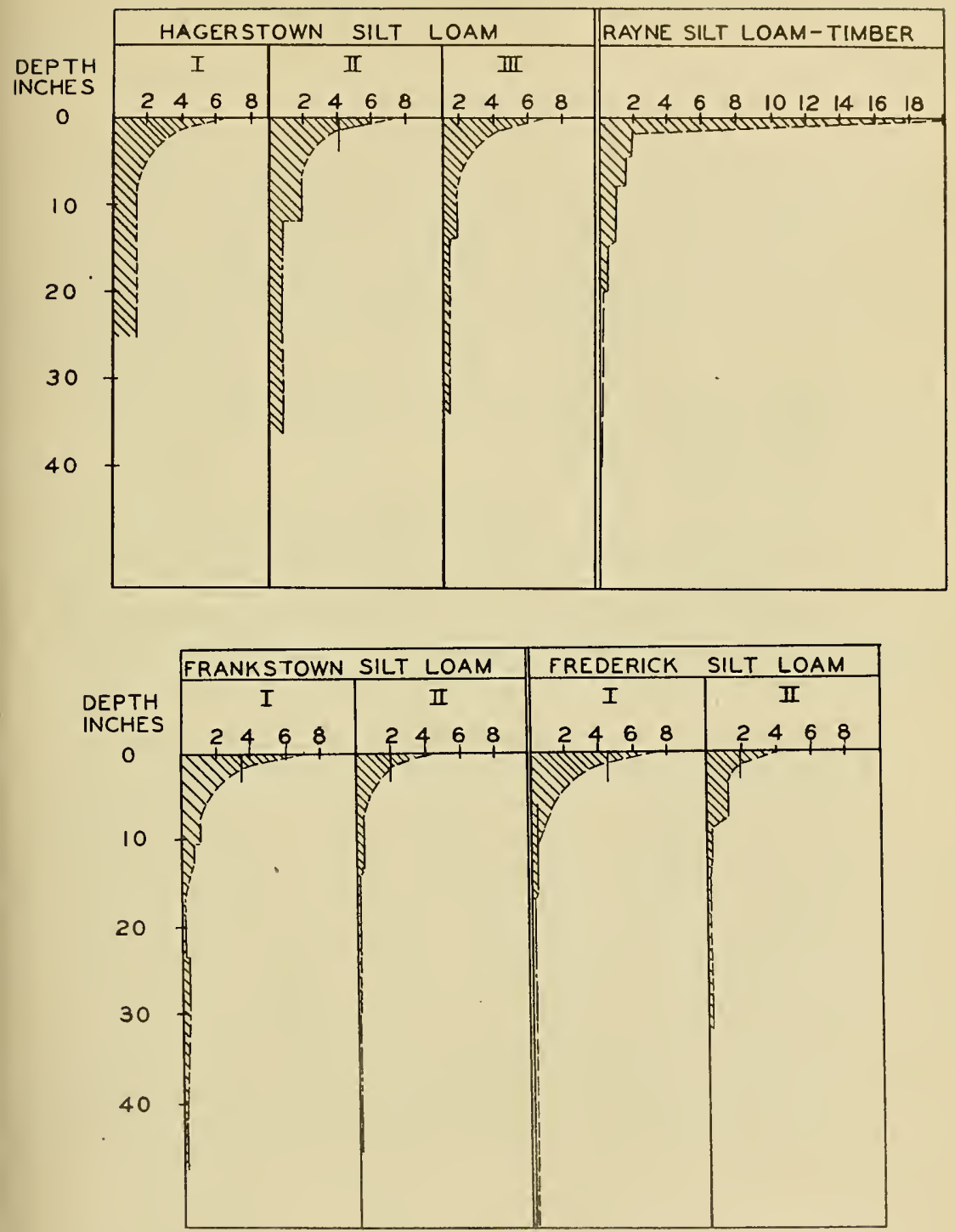

Fig. 6-- Organic-matter distribution in several typical soil profiles. Sctual velues obtained for a particulur depth are indicated with solid lines. Dashed lines represent interpolations. it the surface an interpolation from 0 to 3 inches is shown corresponding approximately to the characteristic distribution shown in Table 1. 
are strongly leached but are responsive to treatment. Younger upland solis have less distinct subsoll units, and their fertility is more closely related to the nature of the parent material.

\section{ORGANIC MATTER}

Attention has been directed to some relationships between organic matter and soll structure. In addition to these physical effects reflected in structure, organic matter is known to be closely correlated with total nitrogen and with the avaliability of nitrogen and other nutrients. These relationships afford some basis for considering organto matter as one of the best indices of soil productivity, although it is recognized that variations in the quality and the turnover of organic matter are factors which must be considered as well as the total amount.

In West Virginia only limited data have been published as to the amount and distribution of organic matter throughout the various solis and under various conditions within the state. A better understanding of the location of soll organic-matter reserves seems essential to any further study and interpretation of its properties and functions.

\section{Distribution of Organic matter in So11 Profiles}

It is not possible to show many clearly defined differences among soil types on the profile basis, but certain gereral features of profile distribution can be shown. Figure 6 shows the rapid organic-matter decrease with depth which is so 1 mortant in understanding West Virginia upland soils. If the plow layer were removed, as by erosion, it is clear thet the outstanding loss would be the organic reserve. With Hagerstown the subsoil reserve of organic matter appears considerably greater than with Frankstown or Frederick. The distribution shown for these latter two limestone solls is not unlike that for the upland sandstone and shale solis. Other dete could be given, but the general picture would be the same.

The Frankstown and the Frederick soil profiles showing lowest orgenic matter in the surface are from areas known to have been cultivated, whereas the two higher profiles have not been cultivated in recent years, if at all. None of the three Eagerstown profiles has a record of cultivation.

The relatively high value for the 23 or 28 -inch leyer in 
one of the Frankstown profiles is belleved to represent a fault in the method of determination, as discussed under Method," because it does not appear reasonable and does not correspond with welght losses by these successive horizons on prolonged heating at $400^{\circ} \mathrm{C}$.

One timber (mixed oak) profile is shown for comparison with pasture profiles. The extreme concentration in the immediate surface is typical of three profiles studied from timber areas. The leaf litter is not.shown, although the distinction between litter and the surface soll is necessarily rather arbitrary. The amount and distribution below the immediate surface do not seem much different from the solls in pasture.

Among upland solis no other clearly significent differences between soll types have been established as yet. If terrace solls and bottom lands are included, it appears that the approximate extremes within the state can be established for pasture and cultivated lands. In a broad, flat lowland at the divide between the headquarters of Muddlety and I1ttle Beaver Creeks in Nicholas County, black silty-clay soll occurs which is classified as Blago silty clay. It is apparently a "hal--bog" soil $(22,24)$ kept molst by seepage from the upland. A 6-inch surface composite from a hay field showed 17 percent of organic matter, whereas similar surface samples from adjacent hay land showe 11.2 and 11.7 percent respectively. On the Homestead land at Dalley; Randolph County, two 6-inch surface-soil samples that were similar in appearance to that from N1cholas County showed 11.0 and 10.9 rercent of organic matter. Thus it seems that an average of 10 percent or more of organic matter is rather characteristic for this soll. The surface layer appears nearly unfform to a depth of 10 to 12 inches, where it grades through lighter colors into a highly mottled subsoll of grey, rust brown, and bluish grey. At 20 to 30 inches free water is evidently present most of the t1me because of the slowness of subsoll drainage or because of water under a hydraulic head in a permeable underlying stratum.

At the other extreme (exclusive of severely eroded areas), we can apparently place the low-altitude, light-textured terrace solls. For example, the Wheeling fine sandy loam at the Iakin Experiment Farm has an average organic content in the plow layer of about 1.2 percent. It varied from 0.65 percent to about 2.0 percent for 43 different rlots recently determined, depending upon the cropning history and other factors. These values are for soll that is quite oroductive with the 
proper treatment and rotation of crops (27). Production is evidently maintained by a high turnover of organic matter rather than by building a large reserve to drqu upon, although corn yield showed a rather close relation to increases in organic matter even within the small range covered. The sandy texture nrovides a desirable physical melium for growth even without much organic matter. The low altitude and relatively high average temperature at lakin contribute to rapid destruction of organic matter and turnover of nutrients.

Another example of relatively low organic matter in light-textured terrace soils is obtained from experimental pasture plots on Nonongahela fine sandy loam at Wardensville. The surface $1 \frac{1}{2}$ inches averaged about 2.4 percent for 24 composite samples, the $1 \frac{1}{2}$ to 3 -inch layer, 1.4 percent. This would be about the same as the values for the Wheeling soil if the resuits were complete to plow depth. It is also about the same as the results for Holston silt loam for Wirt county in Table 1 and for three pasture soil nrofile samples from Tolston loam, where the surface 6 inches had 1.6 percent, 1.3 percent, and 1.2 percent of organic matter, respectively. All of these results are for samp?es below 1000 feet in altitude.

It appears from these extremes that the practical range of organic matter is from 1.0 percent to about 10.0 percent. It would seem doubtful whether profitable cropring of any kind could be maintained under West Virginia soil conditions at an organic "evel below 1 percent. This low value, as indicated, would not be expected to give satisfactory results on any except certair light-textured soils, where a high degree of aeration of the surface layer is attained. Erosion would be difficult to control on such soil if it occupied an appreciable slope, and a rapid organic matter turnover from legumes or barnyard manure would be required.

The IC percent value is only to be expected for an entire plow layer in the case of a relatively permanent water table close to the surface as described for Blago. It is approached by small areas of upland over perched water tables, particularly at high elevations.

Distribution of Organic Natter In the Surface Soll under Pasture Vegetation

Because of the importance of the immediate soll surface as the main root zone for shallow-rocted plants and new seedlings in pastures, and because of the important influence of this layer unon infiltration and erosion, some details of the 
TARLE 1--COMPARISON OF ORGANIC-MATTER CONTENTS IN SEVERAL PASTURE SURFACE SOILS AT TWO DEPTTS AND UNDER DIFFERENT TREATMMNTS

\begin{tabular}{|c|c|c|c|c|c|c|}
\hline COUNTY & $\begin{array}{l}\text { DEPTH OF } \\
\text { SAMPIE } \\
\text { (inches) }\end{array}$ & $\begin{array}{l}\text { SOIL } \\
\text { TYPES }\end{array}$ & $\begin{array}{l}\text { SOIL } \\
\text { TREATMENY"** }\end{array}$ & $\begin{array}{c}\text { YEARS } \\
\text { SINCE } \\
\text { TREATED }\end{array}$ & $\begin{array}{l}\text { PASTURE } \\
\text { HERBAGE }\end{array}$ & $\begin{array}{l}\text { ORGANIC } \\
\text { WATIER } \\
\text { (percent)* }\end{array}$ \\
\hline $\begin{array}{c}\text { Monongelia } \\
n \\
n\end{array}$ & $\begin{array}{l}0 \text { to } 1 \frac{1}{2} \\
1 \frac{1}{2} \text { to } 3 \\
0 \text { to } 1 \frac{1}{2} \\
1 \frac{1}{2} \text { to } 3\end{array}$ & $\begin{array}{l}\text { Gilpin } \\
\text { Silt } \\
\text { Loam }\end{array}$ & $\begin{array}{l}\text { None } \\
\text { None } \\
\text { N P K I }\end{array}$ & 8 & $\begin{array}{l}\text { Poverty grass } \\
\text { \& weeda } \\
\text { Bluegrass \& } \\
\text { White clover }\end{array}$ & $\begin{array}{l}5.49 \\
2.72 \\
5.54 \\
3.06 \\
\end{array}$ \\
\hline Wirt & $\begin{array}{l}0 \text { to } 1 \frac{1}{2} \\
1 \frac{1}{2} \text { to } 3 \\
0 \text { to } 1 \frac{1}{2} \\
1 \frac{1}{2} \text { to } 3\end{array}$ & $\begin{array}{l}\text { Holston } \\
\text { Monongahela } \\
\text { Loam }\end{array}$ & $\begin{array}{l}\text { None } \\
\text { N P I }\end{array}$ & 6 & $\begin{array}{l}\text { Poverty Grass } \\
\text { Bluegrase \& } \\
\text { White clover }\end{array}$ & $\begin{array}{l}2.34 \\
1.48 \\
2.82 \\
1.62 \\
\end{array}$ \\
\hline Roane & $\begin{array}{l}0 \text { to } 1 \frac{1}{2} \\
1 \frac{1}{2} \text { to } 3 \\
0 \text { to } 1 \frac{1}{2} \\
1 \frac{1}{3} \text { to } 3\end{array}$ & $\begin{array}{l}\text { Upshur } \\
\text { Silty } \\
\text { Cley }\end{array}$ & $\begin{array}{c}\text { None } \\
n \\
N \\
n\end{array}$ & 6 & $\begin{array}{l}\text { Broomsedge } \\
\text { Broomsedge \& } \\
\text { ihite clover }\end{array}$ & $\begin{array}{l}5.45 \\
1.93 \\
5.85 \\
2.70 \\
\end{array}$ \\
\hline Putnam & $\begin{array}{l}0 \text { to } 1 \frac{1}{2} \\
1 \frac{1}{2} \text { to } 3 \\
0 \text { to } 1 \frac{1}{2} \\
1 \frac{1}{2} \text { to } 3\end{array}$ & $\begin{array}{l}\text { Zoer } \\
\text { Silt } \\
\text { Loam }\end{array}$ & $\begin{array}{c}\text { None } \\
n \\
2 \mathrm{P} L\end{array}$ & 3 & $\begin{array}{l}\text { Poverty gress } \\
\text { White clover } \\
\text { \& bluegrass }\end{array}$ & $\begin{array}{l}3.52 \\
1.73 \\
3.78 \\
1.72\end{array}$ \\
\hline Rardy & $\begin{array}{l}0 \text { to } 1 \frac{1}{2} \\
1 \frac{1}{2} \text { to } 3 \\
0 \text { to } 1 \frac{1}{2} \\
1 \frac{1}{2} \text { to } 3\end{array}$ & $\begin{array}{l}\text { Iitz } \\
\text { Silt } \\
\text { Loam }\end{array}$ & $\begin{array}{l}\text { None } \\
n \\
2 P L\end{array}$ & 2 & $\begin{array}{l}\text { Poverty gress } \\
\text { Poverty grass }\end{array}$ & $\begin{array}{l}3.87 \\
2.06 \\
4.14 \\
2.15\end{array}$ \\
\hline Greenbrier & $\begin{array}{l}0 \text { to } 1 \frac{1}{2} \\
1 \frac{1}{2} \text { to } 3\end{array}$ & $\begin{array}{l}\text { Frederick } \\
\text { Grevelly } \\
\text { Loam }\end{array}$ & Variable & 3 & $\begin{array}{l}\text { White clover, } \\
\text { Bluegress \& } \\
\text { Weede }\end{array}$ & $\begin{array}{r}4.79 \\
2.57 \\
\end{array}$ \\
\hline Monongalia & $\begin{array}{l}0 \text { to } 1 \frac{1}{2} \\
0 \text { to } 1 \frac{1}{2} \\
0 \text { to } 1 \frac{1}{2} \\
\text { (close- } \\
\text { clipped) } \\
0 \text { to } 1 \frac{1}{2} \\
\text { (cut for hayl }\end{array}$ & $\begin{array}{l}\text { Rayne- } \\
\text { Cookport } \\
\text { S11t }\end{array}$ & $\begin{array}{l}\text { None } \\
\text { P K I } \\
\text { Veriable }\end{array}$ & 7 & $\begin{array}{l}\text { Bluegress } \\
\text { Bluegrass } \\
\text { Bluegrass } \\
\text { Bluegress }\end{array}$ & $\begin{array}{l}2.88 \\
2.93 \\
2.70 \\
3.14\end{array}$ \\
\hline
\end{tabular}

* Averagea of composite samples from each of 4 replicated plots.

** $N, P, K$, and I refer to standard rates of application of nitrogen, phosphorus, potash, and lime, respectively. 
normal distribution with depth in pastures are given (Table 1). The organic-matter content of the first $1 \frac{1}{2}$ inches is seen to average twice that of the $1 \frac{1}{2}$ to 3 -inch layer. The $1 \frac{1}{2}$ to 3 -inch layer has 63 percent as much organic matter as the 0 to $1 \frac{1}{2}$-inch layer for untreated Holston loam in Wirt County, whereas untreated Upshur clay shows only 35 percent as much at the $1 \frac{1}{2}$ to 3 -inch depth. The smaller difference with depth on the light-textured Holston and the greater difference on the heavy Upshur are probably related to the textural classes represented.

It is well to note from Table 1 that pasture treatment has apparently caused a slight increase in organic matter at both denths; but there is no indication that natural organicmatter differences among the various solls could ever be eliminated by treatment. That is, treated Holston loam shows only 2.82 percent after 6 years, whereas untreated Upshur Clay has 5.45 percent or almost twice as much organic matter. These differences seem rather characteristic of the soll types.

Table 1 shows also an apparent increase in organic matter at one location as a result of infrequent cutting of Kentucky bluegrass for hay compared with close clipping. This evidently results from increased root development, since higher forage yields were removed from the hay plots.

\section{Effects of Climate and Cropping} on Soll Organic Matter

The effects of rainfall, temperature, and cropping on organic matter and nitrogen have been subjected to considerable study $(20)$. On the basis of the relationships which have been worked out between organic matter and these factors, it was expected that considerable variation would be found in West Virginia because of the wide climatic and cropping differences represented. From observation, it appeared that the Gilpin silt loam of Nicholas County and other associated areas at high elevations had more surface organic matter than the Gilpin of Wetzel County and associated low altitudes. A number of surface samples from these two counties afford a comparison which shows this difference and its magnitude (Table 2). The samples from both counties are confined to areas which appeared to have suffered from moderate to slight erosion. Meigs samples (a complex of Gilpin and Upshur) show essentially the same organic content as the associated Gilpin from Wetzel County, whereas the Gilpin from Nicholas is 35 percent higher. Total base and $\mathrm{pH}$ differences are included to show that there was a real basis for the distinction be- 
tween the Gilpin and Meigs composite samples from Wetzel County.

TABLE 2--ORGANIC-MATTER COMPARISONS OF' SURFACE SOIIS

\begin{tabular}{|c|c|c|c|c|c|c|}
\hline COUNTY & $\begin{array}{l}\text { APDROX. } \\
\text { EIEV. }\end{array}$ & $\begin{array}{l}\text { SOII } \\
\text { TYPE* }\end{array}$ & $\mathrm{pH}$ & $\begin{array}{l}\text { TOTAI } \\
\text { BASES }\end{array}$ & $\begin{array}{l}\text { NO. OE } \\
\text { CONPOSITE } \\
\text { SAMPLES }\end{array}$ & $\begin{array}{l}\text { ORGANIC } \\
\text { MATTER } \\
\text { (percent) }\end{array}$ \\
\hline Nicholas & 2000 & All upland & 5.30 & 8.8 & 22 & 3.35 \\
\hline Nicholas & 2000 & Gilpin & 5.16 & 7.6 & 16 & 3.13 \\
\hline Wetzel & 700 & AlI upland & 5.24 & 12.7 & 26 & 2.26 \\
\hline Wetzel & 700 & Meigs & 5.46 & 15.0 & 8 & 2.38 \\
\hline Wetzel & 700 & Gilpin & 5.13 & 11.1 & 11 & 2.35 \\
\hline
\end{tabular}

*All silt loams with slight or moderate erosion from tilled or tillable land.

It seems likely that the higher average organic-matter content of surface solis from Nicholas County compared with Wetzel county is to a considerable extent the result of lower average temperature and higher rainfall in Nicholas County. It is also possible that the factor of cropping is involved, since Wetzel has been farmed longer than Nicholas, but climate is probably the major factor of difference (49).

As an indication of the organic-matter differences to be expected from cropping, results with originally uniform soll in bin plots on the Agronomy Farm at Morgantown may be cited. After three years of cropping, the extreme organic contents of the surface three inches were 1.87 percent and 2.35 percent for continuous buckwheat and continuous Korean lespedeza, respectively. Various values are as follows:

Organic Matter (percent)

Korean lespedeza (nothing removed)

2.35

Kentucky bluegrass and white clover

(clippings removed)

2.31

Continuous corn (rye/vetch winter cover)

2.28

Corn, wheat, clover rotation

2.20

Continuous wheat

2.00

Continuous corn

1.92

Continuous soybeans

1.88

Continuous buckwheat

1.87

In the fourth year of cropping with 4-12-4 fertilizer at 500 lbs. per acre annually, the continuous corn yielded less than half as much as the corn with cover crop plowed un- 
der. In this case, the fertility balance of the soil growing continuous corn, with the organic matter depleted to less than 2 percent, was such that a very poor corn crop resulted, although the season was normal, the soll reaction was about pF 6 , and the crop received 4-12-4 fertilizer as indicated. Where a rye/vetch cover crop was plowed under and the organic reserve was somewhat higher, the continuous corn produced a normal crop of about 40 bushels per acre.

It has been shown in Ohio (43) that higher organic matter levels characterize the surface soil under spaced trees in pastures than in adjacent open-pasture areas. Several Greenbrier County samples ( 0 to 3 -inch depth) supplied by Soil Conservation Service District personnel show a similar relationship:

\begin{tabular}{lccc} 
& \multicolumn{2}{c}{ AVERAGE } & ORGANIC MATTER \\
\cline { 2 - 4 } TREE SPECIES & $\frac{\text { Under Trees }}{\text { Tpercent) }}$ & $\frac{\text { Open Pasture }}{\text { (percent) }}$ & $\begin{array}{l}\text { NUMBER OF } \\
\text { COMPARISONS }\end{array}$ \\
\hline Black locust & 3.78 & 2.80 & 8 \\
Black walnut & 4.23 & 3.51 & 6 \\
Oak & 3.83 & 3.08 & 2 \\
Hi ckory & 4.95 & 3.15 & 1 \\
Apple & 4.23 & 3.51 & Composite \\
& & & from 6 trees \\
\hline
\end{tabular}

It is likely that the cooler micro-climate under the trees, together with the organic matter supplied by tree leaves, accounts for these differences.

\section{ACIDITY, BASE SATURATION, AND BUFFERING}

It is a useful concept to think of solls not only in terms of their acidity and base content but also in terms of their buffer capacities toward a base or an acid. If this approach is adopted, it is relatively simple to visualize the interrelations of Iime reouirement, $\mathrm{pH}$, total bases, and percentage saturation with bases. Whether the soil is in its netural state of base saturation or has been shifted upward along its buffer curve by liming, or lowered by leaching and heavy cropping, the relationships are clarified by keeping, the buffer curve in mind. For the curves shown in Figure 7, the zero point represents the $\mathrm{pH}$ when all exchangeable bases are removed. Natural solls at $\mathrm{pH} 4,5$, or 6 occupy varying positions on the right. If we consider $\mathrm{pH} 7$ as the ultimate aim of field liming and hence as essential saturation, the buffer curve of any soil shovis at a glance the base saturation, $\mathrm{pH}$, exchangeable bases, and the base requirements to bring about 
a particular p $\mathrm{c}$ cinee.

The slope of the curve at any point is an indication of the capacity of the soil to resist a change in its $\mathrm{pH}$. If we know the soil $\mathrm{pH}$ we still need to know the nature of the buffer curve in order to predict the lime requirement, the base reserve, and other soil properties. The slope and the shape of the buffer curve's of West Virginia soils are quite variable, but within the practical range from $\mathrm{pH} 4.5$ to 6.5 , most curves are essentially straight lines. The slope is ordinarily the most important consideration. Among normal soils the slope differences shown are not unusual, with the clay or organic soils requiring several times as much base as a silt loam to brine about a particular change of $\mathrm{pH}$.

\section{$\mathrm{pP}$ and Base Saturation}

Considerable work has been done on the relation of $\mathrm{pH}$ to the base saturation of soils. In a recent sumary of literature on the subject Pierre and Allaway (35) reached the conclusion that the bulk of the existing evidence indicated that percentage saturation was the most important factor in determining crop response relative to the bases of soils. In some of his work Pierre showed that percentage saturation seemed to have more signfifcance than total bases or $\mathrm{pH}$, and he indicated that, whereas $p H$ and saturation were generally related, there were serious deviations from the relationship.

Robinson (40) showed that for 0 to 3 -inch samples in West Virginia pastures, the $\mathrm{pH}$ correlated rather closely with percentage saturation and seemed to be more important than total bases in determining the stand of Kentucky bluegrass and white clover.

There are various evidences that the amount of base present and the ratio of different ions are also important factors (1), and in a recent study Mehlich and Colwell (28) showed that with montmorillonitic clay types, percentage saturation was dominant, whereas with kaolinitic clays the total amount of base was more important than the percentage saturation. They also showed that large amounts of exchangeable $\mathrm{H}^{+}$might be detrimental to plants at a constant degree of saturation of montmorillonitic clays. Both of these clay types are probably represented in West Virginia soils, and it may some day become practical to adjust lime recommendation in conformity with clay type as well as other factors.

Another factor regarding base saturation which has probably received insufficient emphasis is the role of organic 
matter. As decomposition rrogresses, various nutcients are released. One result is that base-saturation conditions throughout the soil become quite variable, so that regardless of the arerage condition there would be local areas where the plant could obtain nutrients, whether it be total amount, saturation, or other factors which dominated root intake. Thus it would seem that, where organic matter is the main base-exchange material as in as many Hest Virginia surface soils, there can be little doubt that both total amount of and nercentage saturation with bases are important factors.

With these relationships in mind, soil pH was plotted against percentage base saturation, using acetate leaching at $\mathrm{pH} 7$ as the standard of saturation. The results, summarized in Figure 8, show a fairly close correlation, although there are some rather wide variations where $\mathrm{pH}$ might give a seriously inaccurate indication of percentage saturation based on the average value.

Two points shown as having zero saturation were obtained by thorough leaching with dilute $\mathrm{HCl}$ and washing with distilled water. Electrodialyzed bydrogen clay with no bases, from the Hagerstown soll, shows an initial pH as low as 3.2 , but it tends to come up to 3.8 to 4.0 on standing. With natural soils of the state a pH of about 4.1 seems more or less of an absolute minimum. This low value has been record-. ed for several samples not shown in this comparison. Values much lower than 4.0 seem to be a safe indication of acid mine water damage, which is a fairly common occurrence in the coal-mining sections.

Since so much importance is attached to percentage saturation by plerre and others $(34,35)$, and since it is not always convenient to.determine total exchange capacity, an at tempt was made to improve the accuracy of the pH/base saturation relationship by taking total bases into account. This was suggested by the fact that, at a particular pH value, soils with highest base contents usually proved to have the highest degree of saturation. By taking this into account in a purely empirical way, a graph is obtained (Fig. 9) from which the percentage saturation is read horizontally from the crossing of the vertical pH line and of the diagonal line corresponding to the base content. The accuracy of the chart is improved by subdividing the lowest diagonal into three textural groups. As an illustration, a soil with pH 5 and $15 \mathrm{~m} . e$. of base by acetate leaching would have an expected saturation of 72 percent. 


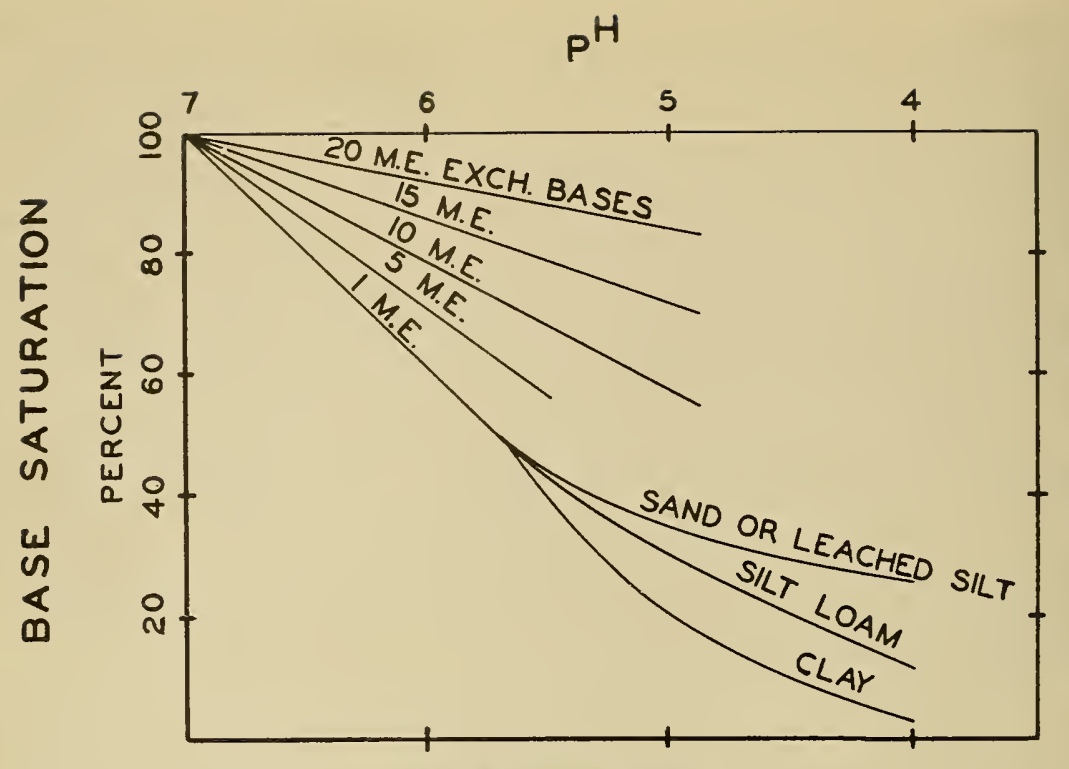

Flg. 9-- General rolo-

tionships among $\mathrm{pH}$, exchange-

ablo beees, and percentago bese-seturation for a wide

variety of West Virginia sur-

faca and subsolis. By con-

sidering the exchangeeblo

bases as well as the $\mathrm{pH}$ an

Improved estimetion is obtrined of percentage base-

1
1
0
$\frac{1}{1}$
$\frac{1}{0}$
$\frac{1}{0}$
$\frac{1}{0}$
0

seturation.

un
on

F1g. 10-- The relation between percontage bese-seturation as determined in the laboratory and as estimatod from $p H$ and exchangeablo-base messuremente (F1g, 9). 
Figure 10 shows the relation of situration values predicted by the chart and actual values determined. It is obvious that this consideration of base contents and texture has provided an improved prediction of saturation. Considerable variation among samples is still evident, but the prediction of saturation appears satisfactory for most practical purposes, considering that such varied soil materials are involved in the comparison. It is likely that differences in the time of the year at which samples were taken and in the degree of dryness attained in the laboratory are responsible for some variations in $\mathrm{pH}$, but it is to be expected that there are real differences in the strength or avidity of the soil acids which would prevent a perfect correlation under any conditions (34). qobinson (40) obtained a rather close correlation between $\mathrm{pH}$ and base saturation for 0 to 3 -inch samples in West Virginia pastures without considering any other factor, but such close correlation would hardly be expected with the wide variety of surface and subsoils represented in the present results.

Now that some of the interrelations of soil acidity and bases for West Virginia conditions as a whole have been demonstrated, it seems appropriate to point out certain applications relative to different so11s. First, in a very general way, it is possible to show some characteristics of particular soll types (Table 3). Base data by the Kappen method are used because they are more complete. A few of these results are conversions from acetate determinations by the equation given (Kappen values $=2.1+$ (acetate values) $\times 1.3$ ). Data by both methods are available for most samples, but nothing seems gained by using both values. It is recognized that this table may be criticized for not showing variations within soil types and for showing averages of all horizons within soll profiles, but the generalized picture seems justified if it is kept in mind that wide variations are included in some of the averages and that the results tabulated should be considered as a very seneral representation which might not apply to a specific case or even to an entire area.

In spite of the variations and overlapping of values, there are a number of distinct differences among soil types as shown. It is interesting that $\mathrm{pH}$, percentage saturation, and total bases all correlate fairly well for many of the soils. Outstanding exceptions are generally associated with obvious textural or organic-matter differences. The Blago of Nicholns County has what rppears to be a fair supply of bases, but the higher organic and high clay content result in a low $\mathrm{pH}$ and low saturation. The same is true of the Zoar, Tyler, Purdy group, which were quite high in clay on the averare. With one 
TABLE 3--SOME CENERAL AVERACE DIFF MRENCES IN ACIDITY AND BASES FOR SETERAL SOILS TKCLUDDNG AIL DEPTHS, ONLESS INDICATED

\begin{tabular}{|c|c|c|c|c|c|c|c|}
\hline SOIL & $\begin{array}{l}\text { DOMINANT } \\
\text { TEXIURE IN } \\
\text { PROFIIE }\end{array}$ & $\begin{array}{l}\text { NUM } \\
\text { Loce- } \\
\text { tions } \\
\end{array}$ & $\begin{array}{l}\text { BER OF } \\
\text { Hor1- } \\
\text { zons }\end{array}$ & $\begin{array}{l}\text { AVERAGE } \\
\mathrm{PH}\end{array}$ & $\begin{array}{l}\text { SAMPI BD } \\
\text { PERCENT } \\
\text { SATURATI }\end{array}$ & $\begin{array}{l}\text { TOTAL } \\
\text { RASES* }\end{array}$ & $\begin{array}{c}\text { COMIXNTS AS TO } \\
\text { VARIAEIIITY } \\
\end{array}$ \\
\hline Hagerstown & Silt to clay & 12 & 22 & 6.5 & 95 & 25.3 & Relatively uniform \\
\hline Pradarick & silt loom & 2 & 8 & 5.2 & 46 & 12.0 & Moderately variable \\
\hline Frederick & $\begin{array}{l}\text { Cravelly s1lt } \\
\text { to clay }\end{array}$ & 3 & 20 & 5.0 & 1 & 5.3 & Rolatively uniform \\
\hline $\begin{array}{l}\text { Prankstown } \\
\text { (E. Panhandle) }\end{array}$ & S11t loem & 2 & 8 & 5.8 & 65 & 11.0 & Modarataly varíble \\
\hline $\begin{array}{l}\text { Prankstown- } \\
\text { P1ckaway }\end{array}$ & $\begin{array}{l}\text { Silt loem } \\
\text { (Greenbriar) }\end{array}$ & 4 & 22 & 5.1 & 30 & 5.2 & Moderately variabla \\
\hline $\begin{array}{l}\text { Meigs Surface } \\
\text { Composites }\end{array}$ & S11t loam & 9 & 9 & 5.5 & $66^{(1)}$ & 14.9 & Relatively variable \\
\hline $\begin{array}{l}\text { Gilpin Surface } \\
\text { (Notzel County) }\end{array}$ & S11t loom & 11 & 11 & 5.1 & $60(1)$ & 11.1 & Relatively uniform \\
\hline $\begin{array}{l}\text { Gilpin Surface } \\
\text { (Nicholas Co.) }\end{array}$ & Silt loam & 16 & 16 & 5.1 & $42^{(1)}$ & 7.8 & Relatively uniform \\
\hline Gilpin & $\begin{array}{l}\text { Shaly silt } \\
\text { loam }\end{array}$ & 5 & 12 & 5.2 & & 10.0 & Widely variable \\
\hline Ashby & Silt loam & 3 & 8 & 4.8 & 34 & 5.0 & Veriable with texture \\
\hline Upehur-lieigs & Silt to clay & 2 & 9 & $5.0^{* * *}$ & 70 & 15.9 & \\
\hline Celvin & Shaly loam & 4 & 13 & 5.0 & 38 & 7.2 & Midely variable \\
\hline Rayne-Cookport & S11t $100 m$ & $?$ & 15 & 4.7 & 32 & 5.5 & Pelatively uniform \\
\hline DeYalb & Fine sandy & 2 & 4 & 4.4 & $21(1)$ & 2.5 & Uniform \\
\hline Lakin**** & S1lt $100 \mathrm{~m}$ & 1 & 6 & 5.5 & 66 & 7.2 & Uniform \\
\hline $\begin{array}{l}\text { Folston- } \\
\text { Vonongahela }\end{array}$ & Losm to clay & 4 & 16 & 4.8 & 35 & 4.0 & Relat1vely unfform \\
\hline Summers . & $\begin{array}{l}\text { Loem to silt } \\
\text { loem }\end{array}$ & 3 & 9 & $5.5^{* * *}$ & & 16.4 & Relatively unfeorm \\
\hline $\begin{array}{l}\text { Zoor, Tyler, \& } \\
\text { Purdy }\end{array}$ & $\begin{array}{l}\text { Silt loem to } \\
\text { clay }\end{array}$ & 4 & 12 & 4.9 & 20 & 5.6 & Moderately variable \\
\hline $\begin{array}{l}\text { Blago } \\
\text { (Randolph Co.) } \\
\text { (Nicholas Co.) }\end{array}$ & $\begin{array}{l}\text { Silt to clay } \\
\text { Silt to clay }\end{array}$ & $\begin{array}{l}1 \\
1\end{array}$ & $\begin{array}{l}3 \\
4\end{array}$ & $\begin{array}{l}5.6 \\
4.6\end{array}$ & $\begin{array}{l}63 \\
22(1)\end{array}$ & $\begin{array}{r}12.0 \\
6.5\end{array}$ & $\begin{array}{l}\text { Reletively uniform } \\
\text { Reletively uniform }\end{array}$ \\
\hline $\begin{array}{l}\text { Fire Clays } \\
\text { (Nicholas Co.) }\end{array}$ & Cloy & 2 & 2 & 4.7 & $12^{(1)}$ & 2.2 & Untform \\
\hline
\end{tabular}

* Total bases by the Kappen method. Expressed es m.

** Most of these velueg are based upon acetete laaching. Those marked (1) are from buffer curves with $\mathrm{Ba}(\mathrm{OH})_{2}$.

*** pH valuas probably ralat1valy too low because determination ves made after complete drying and storage.

**** Name not corrolated. 
Tyler subsoil sample, an extreme in unsaturation was reached. This sample, from 36-inch depth, was 72 percent clay (.002mm.) and only 2.7 percent saturater. with base. It seems likely that these various, clays were very acid when they were originally laid down, since none of the leached silts or sands has reached such a low degree of saturation by soll-forming processés.

Low exchange capacities in DeKalb sandy samples provide anotner extreme, the samples averaging 21 percent saturated with only $2.5 \mathrm{~m}$. e. of bases by the acid method. The $\mathrm{pH}$ values of 4.4 are the lowest shown, indicating a more strongly dissociated acid than most samples. The Lakin* soil, a loose, yellow, silty terrace in the Ohio Valley which has been considered as probably originating from wind-deposited material, is somewhat out of line with most samples. Its extreme siltiness is associated with a low exchange capacity and a rather high degree of saturation with only a moderate base content.

From any $\nabla$ iewpoint, the Hagerstown soll as sampled is outstanding for its high bases, high $\mathrm{pH}$, and high saturation. These samples have been limited to soil having rather uniform, typical reddish brown color, well-developed subsoil aggregation, and no gravel. These characteristics seem to typify the series in West Virginis and are consistently associated with strong basic properties.

The Frederick soll as mapped seems quite variable in bases. Some samples approach the Hagerstown, whereas others seem as strongly leached as level shale solls. The silt loam is believed to be much higher in bases and more uniform than the gravelly tyne, as indicated in Table 3 . The grey subsurface layer which commonly occurs in the Frederick is highly silty with very low exchange capacity and very low bases. pH values as low as 4.8 have been obtalned for cherty Frederick subsoll, indicating strong leaching for a limestone soil.

Frankstown silt loam from the Eastern Panhandle is shown separately from that in the Greenbrier Valley on the basis of results to date which seem to indicate a real difference between the two locations. This difference is partly accounted for by the large areas of Pickaway in the Greenbrier, but ever the heart of the Frankstown area as mapped in the recent county soil survey (46) appears to be a more highly lesched soll than the same type in the east, and this observation is

*Name not correlated. 
confirwed by the data in Table 3. The Greenbrier samples are Jesignated as Frankstown-Pickaway on the basis that they seem intermediate between the two types as commonly described. In soll mapping, it is obvious that this intermediate soil would have to be classified into one or the other of the tycical types.

One of the four Frankstown profiles from the Greenbrier was definitely better than the others, both in appearance and in base status, and could readily be classed with the Frankstown from the east. It was found near Frankford, where it seemed to represent a considerable area on several farms. If this profile were omitted from the averages, the base content of the remaining three profiles would be $4.5 \mathrm{~m} . \mathrm{e}$.) the $\mathrm{pH}$ 5.0 , nnd the saturation 27 percent. Base values down to 1.9 m.e. were obtained for lower subsoil, which is about as low a value as is ever obtained with the acid method. Such material evidently is rainly ouartz sand and silt.

The Meigs surface samples from Wetzel County and two Upshur-Meigs profiles represent the only other soils with Iimestone influence, and they show the influence distinctly. Meigs, of course, is a complex rather than a distinct type, consisting of Gilpin (acid-shale) and Upshur (red clay-shale, mainly limey). The Upshur-Veigs profiles had obvious red clay-shale influences but were not typical Upshur. The lime influence is distinct, although some low $\mathrm{pH}$ values were obtained.

Gilpin surface samples afford an interesting comprison between Netzel and Nicholas Counties. These same samples have been compared as to organic matter content. The base and saturation differences are almost as distinct as the cortrast in organic matter. It appears that the organic exchange material from Nicholas County has a relatively low iegree of dissociation of hydrogen compared with the exchange material of the Wetzel county samples. This is shown by the fact that the $\mathrm{pH}$ values are essentially the same, whereas the saturation is lower in Nicholas County. Another way of stating this would be that the Nicholas County samples show strongest cuffering at relatively hich $\mathrm{pH}$ values, which is consistent with Baver's (3) conclusions that most of the bus-fering by organic matter starts in the range of slight acidity and continues beyond reutrality. In certain other caso.; this does not seem to be true, suggesting that the type of organic matter must be considered.

Valies obtained for Rayne and Cookport silt loams are 
so far rather consistent, showing a high degree of leaching and not much variation with depth in the profile. Several samples are from soil that is intermediate between the two; hence no distinction is possible.

Holston and Nonongahela are shown together because of the comparatively small number of samples and the fact that two of the profiles sampled are believed intermediate between the two soil series and therefore not suited for drawing any distinctions. These soils are strongly leached al though not extremely low in base saturation, suggesting that leaching does not readily lower the bases below a certain percentage saturation.

Giloin, Ashby, and Calvin soil samples have shown great variation in base status, as might be expected from the variations in their parent rock. It would seem important in any localized area of interest to collect samples of the soil and the parent material of these soils to find out the reserve of bases. So far no observable rock characteristics have seemed consistently associated with the different base levels, but every effort is being made to find some useful field index to the base content. Rock and soil testing for lime, pH, and exchargeable bases appears to be the best approach at present. It would seem that such tests together with closer observations of soil depth would provice a valuable guide to the probable success of any deep-rooted crops. Ordinary soiltype distinctions in mapping cannot be expected to provide this needed information.

The samples of Sumers soil were collected in Nicholas and Creenbrier Counties. The soil occurred at elevations apprcaching 3000 feet in close association with light-colored shale soil.s. The samples considered as Sumers were exceptionally dark colored compared with the associated upland, and the dark color was recognized by farmers as having some association with soil productivity. The hich bases shown suggest that the primary source of the fertility and dark color is the brown, rather soft shale or fine-grained sandstone from which the soil is derived. The lowest base value obtained was $11.0 \mathrm{~m} . e$. , which is relatively high compared with most other soils of the area. Potash apparently plays little part ir the fertility of these soils because the exchangeable potassium is lower than the state average (Table 5.) 


\section{Acid/Base Distribution with Depth}

In addition to the genergl features assocleted with certain soil series or types, it is essential to recognize variations within particular soll profiles. The base contents of the profiles of certain soils are given in Figure 1l. These appear typical of the main profile types in the state. Pertinent date on these same soils are given in Table 4.

No. 1, a Hagerstown silt loam profile from Greenbrier County, is not unlike other heavy-textured solls of strong limestone influence and is typical of other Hagerstown profiles studied. High base values throughout, with excess lime in the lower part of the profile, is characteristic. The values for the 9 to 12-inch layer are as low as any base values obtained for Hagerstown. Berkeley, Brooke, and limey Upshur soils show similer distributions of bases with depth.

Profiles 2 and 3 are Frederick silt loam. from the Greenbrier. No. 2 is rather rich in bases, approaching Hagerstown, but neither the total bases nor the $\mathrm{pH}$ values are quite as high as for Hagerstown. A definitely leached zone corresponding to the grey subsurface layer typical of Frederlck silt loam is evident. The increase in bases in the subsoll corresponds with an increase in clay, so that the $\mathrm{pH}$ and the degree of saturation stay about the same. It is easy to visualize that this profile could have been formed from a soll like the No. 1 Hagerstown by the natural progress of leaching.

No. 3 Frederick looked much like No. 2 in the field, but it is obviously more completely leached in the subsurface and subsoll, although the surface retains a high base content. The increased base content from 15 to 30 inches corresponds to a high clay layer, which is probably a real B horizon. The surface content of bases may be influenced by liming.

Profile No. 4 is marked by uniformity of bases and $\mathrm{pH}$. The degree of saturation is more variable and increases with depth below the incipient hardpan at 25 to 30 inches. This seems typical of the various "hardpan" soils (Monongahela, cookport). The profile shown is a highly leached terrace with very little reserve of bases either in the exchangeable or the primary mineral form. It is classed as intermediate between Holston and Monongahela because the color profile is more like Holston, although a recognizable "hardpan" is present. 
TOTAL BASES
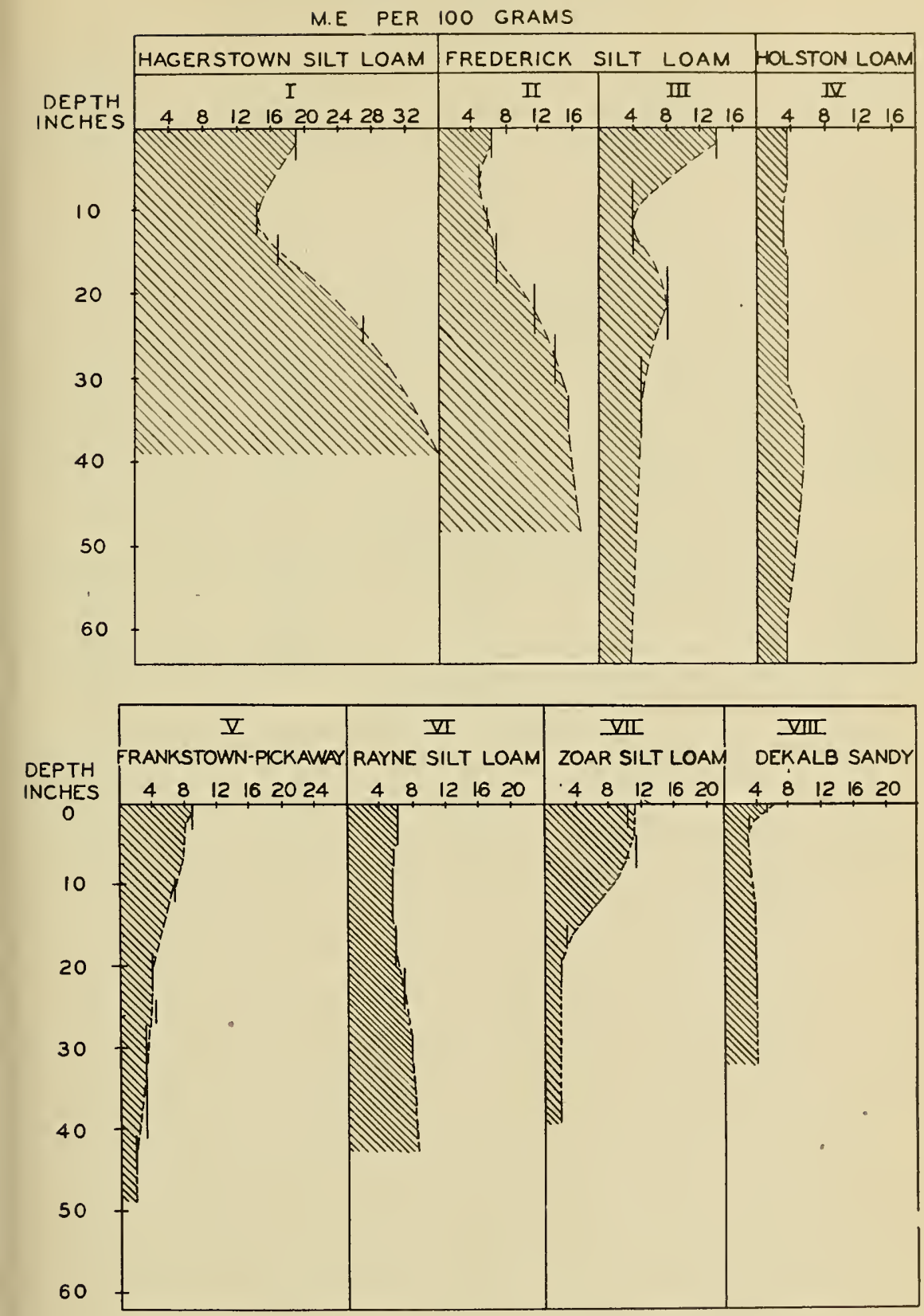

F18. 11-- The distribution of bases with depth in sereral typical soll proflles. Solld lines represent actual determinations; dotted I1nes are interpolations. 
TABLE 4--ACID/BASE DATA FOR THE SEVERAL SOIL PROFILES SHO:NN GRAPHICALLY IN FIGURES $11 \mathrm{a}$ AND $11 \mathrm{~b}$

HAGERSTOHN SIIT LOAM

\begin{tabular}{|c|c|c|c|c|}
\hline & $\begin{array}{l}\text { TOTAL BASES } \\
\text { m. } \theta . / 100 \text { m. }\end{array}$ & $\mathrm{pH}$ & $\begin{array}{c}\text { CIAY } \\
\text { (percent) } \\
\end{array}$ & $\begin{array}{c}\text { BASE } \\
\text { SATURATION } \\
\text { (percent) }\end{array}$ \\
\hline $\begin{array}{l}0-3^{n} \\
9-12^{n} \\
12-15^{n} \\
22-25^{n} \\
29-35^{n}\end{array}$ & $\begin{array}{l}19.0 \\
14.5 \\
16.5 \\
27.0 \\
\text { Free } \\
\text { I1me }\end{array}$ & $\begin{array}{l}6.4 \\
6.8 \\
6.7 \\
6.0\end{array}$ & $\begin{array}{l}18 \\
29 \\
\\
52 \\
\\
65\end{array}$ & 100 \\
\hline
\end{tabular}

FREDERICK SIIT IOAM

\begin{tabular}{lrlll}
\hline $0-3^{n}$ & 6.6 & 5.8 & 10 & 48 \\
$3-6^{\prime \prime}$ & 4.7 & 5.3 & 12 & 26 \\
$9-12^{n}$ & 6.0 & 5.2 & 27 & 46 \\
$12-18^{n}$ & 6.8 & 5.5 & 35 & 51 \\
$18-24^{n}$ & 11.5 & 5.4 & 56 & \\
$24-30^{n}$ & 14.5 & & 58 \\
$32-36^{\prime \prime}$ & 15.4 & 5.4 & \\
\hline
\end{tabular}

FREDERICK SIIT IOHM

\begin{tabular}{lrrrr}
\hline $0-3 n$ & 13.4 & 5.6 & 9 & 55.6 \\
$6-15^{n}$ & 3.9 & 5.5 & 10 & 52 \\
$15-25^{n}$ & 7.5 & 5.2 & 43 & 64 \\
$27-30^{n}$ & 4.7 & 5.0 & 47 & 39 \\
$72-75^{\prime \prime}$ & 3.5 & 4.9 & 39 & 36 \\
\hline
\end{tabular}

HOISTON-MONONGAHELA. IOAN

\begin{tabular}{lllll}
\hline $0-6^{n}$ & 3.8 & 4.75 & 9 & 17 \\
$9-14^{n}$ & 3.5 & 4.9 & 13 & 35 \\
$15-21^{n}$ & 3.7 & 4.8 & 16 & 39 \\
$25-30^{n}$ & 3.7 & 4.7 & 17 & 30 \\
$35-40^{n}$ & 5.2 & 4.8 & 21 & 42 \\
$60-64^{n}$ & 3.5 & 4.9 & 11 & 51 \\
\hline \hline
\end{tabular}


TABLE 4--COINTINUED

FRANKSTOWN-PICKAWAY SIIT LOAM

\begin{tabular}{|c|c|c|c|c|}
\hline & $\begin{array}{l}\text { TOTAI BASES } \\
\text { m.e. } / 100 \mathrm{gm} .\end{array}$ & $\mathrm{pH}$ & $\begin{array}{c}\text { CLAY } \\
\text { (percent) }\end{array}$ & $\begin{array}{c}\text { BASE } \\
\text { SATURATION } \\
\text { (percent) }\end{array}$ \\
\hline $0-3^{n}$ & 9. 0 (L1med) & 5.8 & 10 & 60 \\
\hline $9-12^{n}$ & E. 6 & 5.2 & 30 & \\
\hline $18-23^{n}$ & 4.0 & 5.2 & 41 & \\
\hline $23-27^{n}$ & 4.2 & 5.0 & 43 & 20 \\
\hline $27-41^{n}$ & 3.0 & 5.0 & 54 & 18.5 \\
\hline $41-45^{n}$ & 1.9 & 4.9 & 14 & 21.5 \\
\hline
\end{tabular}

PAYNE SIIT IOAM

\begin{tabular}{lllll}
\hline $0-5^{n}$ & 6.0 & 4.6 & 12 & 13 \\
$5-8^{n}$ & 5.5 & 4.6 & 17 & 17 \\
$8-14^{n}$ & 5.2 & 4.4 & 12 & 12.5 \\
$15-20^{n}$ & 5.7 & 4.5 & 19 & 19 \\
$20-25^{n}$ & 6.8 & 4.6 & 34 & 22 \\
$28-31^{n}$ & 7.8 & 4.6 & 39 \\
\hline
\end{tabular}

ZOAR FEAVY SIIT I OIM

\begin{tabular}{lrrr}
\hline $0-3^{n}$ & 10.2 & 5.6 & 43 \\
$4-8^{n}$ & 11.3 & 5.7 & 30 \\
$15-18^{n}$ & 2.6 & 4.9 & 15 \\
$19-22^{n}$ & 2.0 & 4.9 & 16 \\
$36-39^{n}$ & 2.1 & 4.6 & 7 \\
\hline
\end{tabular}

DEFAIB FINE SNDDY IOHM

\begin{tabular}{lllll}
\hline $0-1^{n}$ & 5.2 & 4.2 & Iow & 15 \\
$1^{\frac{1}{2}-3^{n}}$ & 3.0 & 4.8 & Low & \\
$21^{\prime \prime}$ & 4.0 & 4.8 & 22 & 18 \\
\hline
\end{tabular}


Profile No. 5 is from the Frankstown-Pickaway area of the Greenbrier. It shows some grey, brown, and yellow mottling in the subsoll but is not an extreme pan tyne. At 41 inches there is a definite break through the subsoil into a highly silty and fine sandy layer. The progressive decline in bases with depth indicates thorough leaching. The fact that no evidence of lime enrichment is encountered raises some question as to whether the soil developed from a strongly carbonated stone. If so, the leaching has been complete. Some lime is known to have been added to the surface, which is a good bluegrass/white clover pasture.

Profile No. 6 is Rayne silt loam from Monongalia County. It is a ridgetop soil of acid-shale origin. Leaching is strong through the entire profile, which is apparently typical of the upland shale soils of this area. They are leached through the structural $A$ and $B$ horizons and into what is ordinarily considered the $C$. In a number of deep cores from colluvial soils near Morgantown the profile was quite acid to depths of about 4 feet, below which it became less acid or neutral (17). This seems to be about the normal depth of leaching of upland solls in this vicinity. The leached layer below the structural $B$ horizon probably constitutes a $Y$ horizon as discussed under "Soll. Depth."

Profile No. 8 was taken in oak timber where the soil has never been plowed. It is shown to illustrate the slight build-up of total bases in the shallow organic layer at the surface from a sandy substratum which is poor in bases. The build-up in total bases does not constitute an increase in $\mathrm{pH}$ or percentage saturation, because the bases are associated with a concentration of active organic matter. If this soil were put into cultivation, the decomposition of organic matter would be accelerated with a release of bases and other nutrients which might give one or two satisfactory crops. But after the smali surface reserve was gone, there would be almost no fertility left. This is believed to be typical of the behavior and the history of many highly leached soils. The small surface reserve is mined and then the land is abandoned.

The distribution of bases with depth is an important consideration in any attempted reclamation of severely eroded soils. Subsoils with a fairly larce supply of bases offer considerable promise of success, whereas strongly leached subsolis appear much more hopeless. This is especially true of clay subsoils, where in case of low bases the degree of 
saturation also is low. The fact that large additions of lime would be required is discouraging in itself, but there is the additional factor to consider that low base saturation is 11 kely to be assoclated with low contents of other nutrients such as potash and various minor elements.

Soll tests seems to be the only way to evaluate the base status of many West Virginia soil profiles. The visible characteristics of mature or old soils or of young solis with free lime can be used to judge the acid/base status within reasonable $11 \mathrm{mits}$; but among immature solls without free lime there are w1de variations due to differences in the parent shele which are not necessarily reflected in the appearance of the soll profile. These differences can be readily detected by $\mathrm{pH}$ and total base determinations.

\section{Clay and Organic Matter as the Sources of Base Exchange}

It $1 \mathrm{~s}$ well known that the base-exchange propertles of solis depend to a large extent upon the clay and organic matter present. Both the factors of quality and quantity are involved. In the southern United States clays in general are known to be less reactive than in central or northern regions. Organic matter is also variable in quality. Differences in exchange and other properties are expected from this factor alone.

In order to determine something of the average exchange capacities associated with West Virginie soils relative to their contents of clay and organic matter, Figure 12 was prepared. Multiplication of the organic content by 6 seems justified by the study of various data throughout the state, suggesting that organic matter is roughly six times as active as clay in exchange properties. This would indicate that if clay (.002 mm.) has an exchange capacity of about $32 \mathrm{~m} . \theta$. per 100 grams, then organic matter as determined would have a capecity of about 192. The points so far show a rather close relationship between exchange capacity and this combination factor in West Virginia solls. Deviations from the line are probably due to differences in quality of clay and organic matter (30), and even wider deviations are to be expected as more data accumulate. It is interesting to note that these varied soils fit the line as well as shown and that the points define a line which hits very near zero exchange for zero on the clay/organic matter scale. This tends to confirm that these soils have practically no exchange properties other than from clay and orcanic matter. By way of comnarison 
four points are shown as open circles which were calculsted from data given by Baver (2) for four Ohio solls. These points are all slightly high but conform to the straight-line relationship, suggesting that the $\epsilon$ to 1 ratio for activity of orgenic matter to clay is about right but that the activity for the Ohio soils is slightly higher.

Even though Figure 12 is recognized as applicable only in a general way, it serves to demonstrate the approximate relative importance of hums* and clay in different parts of soil profiles. With most sirface soils of 3 percent or more of organic matter it seems safe to assume that the exchange properties are dominated by the organic complex because most West Virginia surface soils are silt loams or loams with less than 15 percent and frequently less than 10 percent clay. In depleted or eroded solls or in subsurface layers clay or humu may dominate depending upon the particular conditions, wherea: with subsolls the clay is clearly dominant. From this it see. worth suggesting t at the aim in reclaiming eroded solis or even in maintaining high production levels may rest upon a ce tain ratio of organic activity to clay activity. With sandy or silty solis low in active clay, as already discussed under organic matter, it is possible to reconcile low humus content with high production by proper treatments and rotations. The same cannot be said in the case of heavy clays. Fere the humus must be maintained at a higher level for satisfactory results.

\section{Organic Matter, Clay Content, and Exchange Capacity in Relation to Lime Requirement}

As a general guide to the exchange properties of West Virginla soils 1t is possible to set certain limits which can be based upon observation in the field. These differences in exchange capacity are approximately nroportional to lime need to bring about a particular change in $\mathrm{pH}$.

Surface Solls

Exchange capgcity

m.e. per 100 grams

1. Dark-colored

E. Clay

20 to 50

(values above 30 are very uncomon)

b. Silty or sandy 12 to 25

*The terms "humus" and "organic matter" are usen interchangeably. 
Fig. 12-- The relation between exchange capacity and the multiple factor of clay $t$ (\% organic matter) $\times 6$ for a variety of culated from data published by Baver for ohlo soils (2).
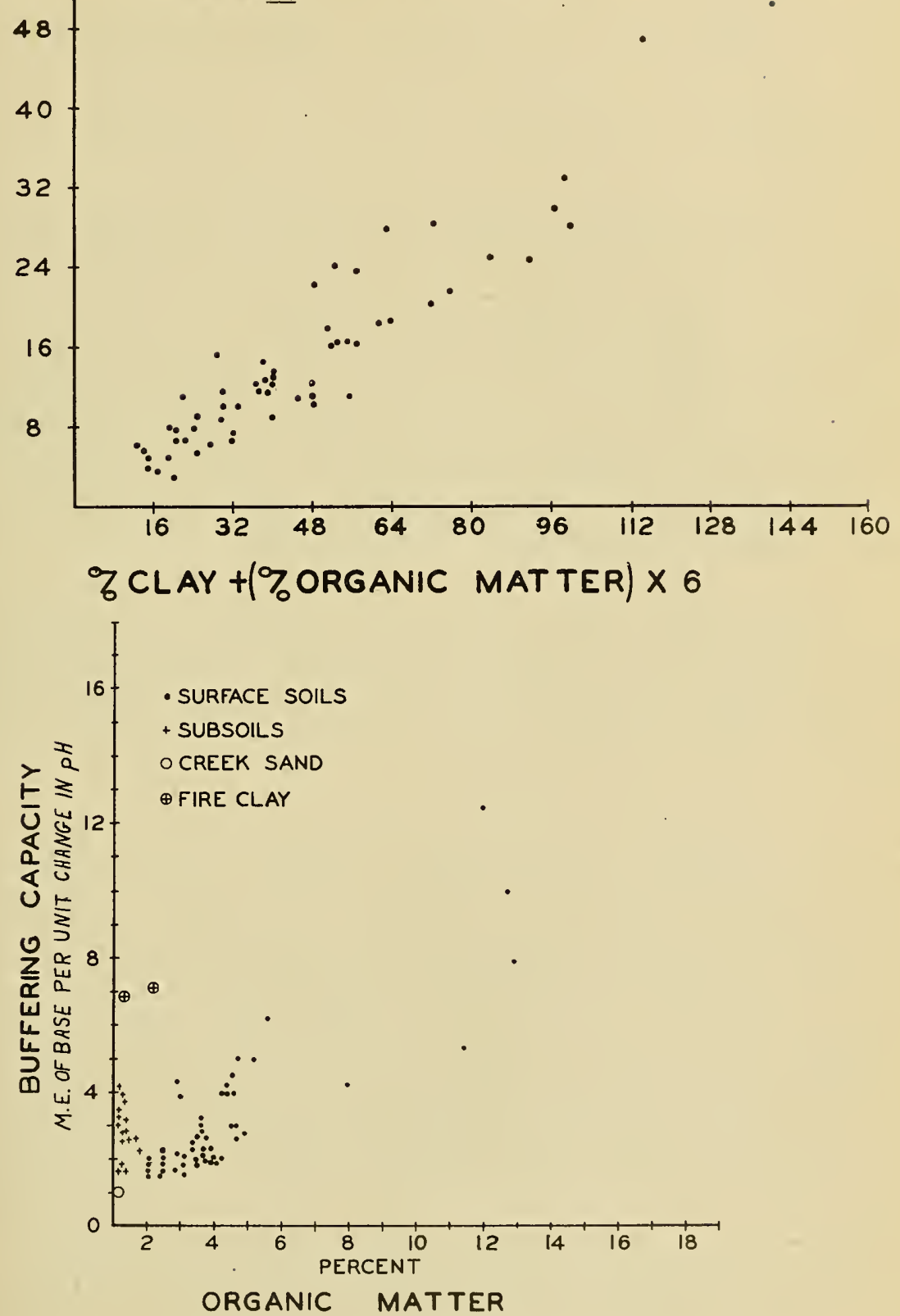

Fig. 13-- The buffering capacity of various iest Virginis soils, showing the strong influence of organic matter among surface soils and the rether wide range among subsoils without regard to organlc content. 
2. Light-colored

$$
\begin{aligned}
& \text { a. Clay } \\
& \text { b. Silty } \\
& \text { c. Sandy }
\end{aligned}
$$

Subsolls $\begin{array}{rrr}10 & \text { to } 25 \\ 5 & \text { to } 12 \\ 3 & \text { to } 6\end{array}$

Exchange Capacity
1. Clay

2. Silty

3. Sandy
10 to 25
5 to 10
2 to 5

A further illustration of the role of clay and organic matter 1s given by Figure 13. Clay as such is not shown, but the vertical range of the subsoll samples is largely a function of the amount and type of clay present. The vertical scale is an index of soil buffering based upon buffer curves of the soils toward $\mathrm{Ba}(\mathrm{OH})_{2}$, as already described. Units on the vertical scale can be changed into pure $\mathrm{CaCO}_{3}$ requirements for plow-layer depths by application of a factor of 1500 , according to the standards established by Pierre and Worley (33). That is, 2 m.e. of base corresponds to 3000 lbs. of lime per acre $?$ 1nches.

It is evident from Figure 13 that humus is ordinarily the dominant source of surface-soll buffering or l1me requirement, whereas with subsolls the variation is due primarlly to another factor, obviously clay. Some of the variablitty among surface solls is probably due to the quality of the organic matter as well as to differences in content of clay.

If organlc matter data are recalled from the flrst part of this bulletin, it can be seen that great changes in buffering are to be expected with depth in the soil profile corresponding to variations in organic matter. The surface $1 \frac{1}{2}$ inches in pasture may require as much lime as the next 3 inches to bring about the same change in $\mathrm{kH}$. Subsoils compared to surface soils recuire less lime for a particular fH change unless there is a great increse in the clay content, because subsolls are so low in organic matter. With most of the shallow shale or sandstone uplands buffering is strongest in the surface soils, but if the surface soll is silty and the subsoll is a clay, the exchange capacity and the lime requirement per unit change in $\mathrm{pH}$ are likely to increase with depth. This is offset in some cases by an increased base content in the clay subsoil, as with Hagerstown, where the subsoll is essertially seturated. In such cases the strong 
buffering is a favorable factor because it represents a reserve of bases which can withstand heavy cropping and leaching losses.

In liming pastures it is sometimes noted that the $\mathrm{pH}$ change of the surface 3 or 6 inches averages less than expected. Determinations of exchangeable bases in several such cases have shown that the high organic content and strong buffering capacity of the immediate surface have caused most of the lime to be caught and held in the shellow surface layer, where the lime requirement on 8 plow-layer basis may approach a rate of 6 tons per acre for each unit of change in $\mathrm{pH}$ (as from $\mathrm{pH} 5$ to $\mathrm{pH} 6$ ).

\section{AVAIIABIE PHOSLHORUS}

After several hundred determinations by the standard Truog method and widespread tests made in the past, only one conclusion is possible--dilute-acid-soluble phosphorus is very low in practically all solls and subsolis of the state unless fertilizers have been added. The method is accurate down to about five parts of phosphorus per million of soil, which is generally considered too low for good growth of nractically all crops except trees. About 20 parts per million ordinarily results in satisfactory yields unless there are other limiting. factors. Robinson (40) indicated that 13 p.o.m. resulted in nearly maximum stands of bluegrass and clover, but responses in yield would be expected beyond that amount.

A very few exceptions may be noted to the low phosphorus rule, although their practical significance is uncertain. On the Homestead land at Dailey, 15 to $16 \mathrm{p} . \mathrm{p} . \mathrm{m}$. of soluble phosphoms was obtained at depths of 2 to $3 \mathrm{feet}$, and near Martinsburg in the Eastern Panhandle from 7 to $40 \mathrm{p} . \mathrm{p} . \mathrm{m}$. of phosphorus was found throughout two Hagerstown soll profiles in pasture, the average being about $15 \mathrm{p} . \mathrm{p} . \mathrm{m}$. This would probably be quite significant if it is widespread, but Hagerstown from the Greenbrier and from several other locations in the east have failed to show appreciable amounts. High soluble-phosphorus tests have also been obtained from subsoil samples in limestone areas near Wardensville and at Kearneysville.

In studying material from strip-mined dumps, high tests for soluble phosphorus have been obtained in a number of cases. If this were an absolute test for avaliable phosphor- 
us, it would be important because attempts are beinf made to reclaim this material for cropping. But plants growing on this same material in the field have been observed as having deficiency symptoms that look like phosphorus dificiency as shown in "Hunger Signs in Crops" (19), and greenhouse tests have shown a marked response to phosphorus. Thus it seems that the test used is not reliable as a measure of available phosphorus with this material.

It is belleved that there may be one other serious complication in testing for phosphorus in the state. The chemical tests in use do not measure the organic phosphorus, which undoubtedly is important, perticularly in soils having a high humus content. This leads to the general conclusion that phosphorus deficiencies as measured by test are ordinarily less severe if the soil contains large reserves or has a rapid tumover of organic matter.

In the analyses of solis reported in 1924 (12) a higher quantity of total phosphorus was shown for the limestone areas of the state and for the soils of generally higher productivity. Since total phosphorus may not be closely related to available phosphorus, this distribution of total reserves may be incidental to the associated soll fertility levels. The excellent response to phosphorus fertilizers on these soils with the relatively high reserves affords stron evidence that the low avallability as indicated by the Truos test is a more realistic plcture of the situation than are the total reserves. The quick response and generally higher fertility of the limestone soils is more likely traceable to such factors as the supply of bases, higher $p H$, superior rhysical properties, and greater soil depths. Even so, it seems worth keeping in mind that larger reserves of phosphorus are ordinarily present in these more fertile soils, and under certain conditions a part of this reserve may become available. The examples of high soluble-phosphorus tests mentioned apparently represent cases where the phosphorus reserve occurs in a more soluble form than in most subscils. Similar variations have been reported for Iowa subsoils (47), but the solubility has not proved to be a very reliable index of availability to plants.

AVAIIARIE DOTLSH

As with phosphorus, there is no absolute measure of potash availability in soils, but in contrast to rhosohorus the 
normal reserves of potash are very large. fnslyses of iest Virginia soils $(5,12,42)$ sinowed an average total of 28,000 pounds of potassium in the plow layer, comoared with only 1100 lbs. of phosphorus. This amount of potash is 1.4 percent, or as much potash as we have organic matter in some soils; hence the high removal of potash by certain plants does not necessarily mean that potash fertilizer is needed at present. Neither does it mean that potash can be neslected as a fertilizer constitutent, for we know that limitations of availability may and do occur, although such limitations are undoubtedly less common than phosphorus limitations.

In studies thus far a few quick tests have been made, but all of the data presented are based upon quantitative determination.

A total of 136 duplicate determinations for surface and subsoils (Table 5) gave an average of $0.256 \mathrm{~m}$.e. of $K$ per 100 grams of soil.* This amounts to 200 lbs. of potassium or 240 lbs. of $\mathrm{K}_{2} \mathrm{O}$ per plow-layer depth. This is considerably lower than the average of $0.38 \mathrm{~m}$.e. obtained for 0 to 3 -inch pasture samples by Robinson (Table 6), but 200 lbs. of avallable potassium per acre plow layer is a fairly abundant sup ly. It would be exhausted in a few years if not renewed, but it is known that there is a continual movement of potash from the non-avallable to the available form as the exchangeable potash is used up (14); and it has been demonstrated that plants can obtain some potash from sources other than the exchange complex, provided there are potash-bearing minerals in the silt fraction (38). The potash outlook for West Virginia solls as a whole is therefore moderately encouraging, althoush the immediately available supply may average only 0.7 percent of the total reserve.

There is wide variability with many low as well as high values for exchangeable potash. The highest obtained was 0.047 percent or 940 lbs. per acre for a dark-colored, heavy textured upland surface so11; the lowest was 0.002 percent or 40 pounds per acre for both a silty lower subsoll and for two leached, silty surface soils. On the average, surface soils are highest- $0.35 \mathrm{~m} . \theta$. for 44 surface soils as comnared to $0.21 \mathrm{m.e}$. for 92 subsoils, but the average for subsoils is

*m.e. per 100 grams is converted to pounds of K2O per acre by multiplying by 939 . 


\begin{tabular}{|c|c|c|c|c|c|}
\hline SOIL & $\begin{array}{l}\text { NO. OF } \\
\text { IOCATIONS }\end{array}$ & SAMPLES & $\begin{array}{l}\text { EYCHUNGEIBIE } \mathrm{K} \text {. } \\
\text { m.e. / } 100 \mathrm{gm} \text {. } \\
\text { Av. }\end{array}$ & KIGMEST & IOHEST \\
\hline All Prof1les & 45 & 136 & 0.256 & 1.24 & 0.04 \\
\hline $\begin{array}{l}\text { All profile } \\
\text { Surfaces }\end{array}$ & 44 & 44 & 0.351 & 1.24 & 0.04 \\
\hline $\begin{array}{l}\text { All profilo } \\
\text { subsolls }\end{array}$ & 45 & $9 ?$ & 0.2 .12 & 1.00 & 0.04 \\
\hline $\begin{array}{l}\text { Molston- } \\
\text { Monongehela }\end{array}$ & 3 & 22 & 0.12 & 0.18 & 0.04 \\
\hline $\begin{array}{l}\text { (Greenbrier) } \\
\text { Frankstown-Pickaway }\end{array}$ & 2 & 12 & 0.15 & 0.26 & 0.04 \\
\hline Eakin S1lt & 1 & 6 & 0.18 & 0.27 & 0.05 \\
\hline Calvin & 3 & 9 & 0.18 & 0.29 & 0.10 \\
\hline DeYaIb sandy & 1 & 1 & 0.05 & & \\
\hline Rayne & 3 & 11 & 0.22 & 0.31 & 0.09 \\
\hline Frederick & 3 & 13 & 0.33 & 0.86 & 0.08 \\
\hline Hagerstown & 3 & 10 & 0.35 & 0.66 & 0.10 \\
\hline I1tz $811 \mathrm{t} 10 \mathrm{~m}$ & 2 & 4 & 0.25 & 0.35 & 0.05 \\
\hline $\begin{array}{l}\text { Zoar, Tyler, Purdy, } \\
\text { Blago, Atkins }\end{array}$ & 12 & 21 & 0.21 & 0.68 & 0.07 \\
\hline $\begin{array}{l}\text { Calcareous olack- } \\
\text { water terrace }\end{array}$ & 1 & 5 & 0.21 & 0.24 & 0.17 \\
\hline Surmers & 2 & 5 & 0.19 & 0.28 & 0.09 \\
\hline $\begin{array}{l}\text { Ashby, Glipin, and } \\
\text { other ac1d shales }\end{array}$ & 7 & 15 & 0.43 & 1.00 & 0.09 \\
\hline $\begin{array}{l}\text { Upghur } \\
\text { Melgs }\end{array}$ & 2 & 10 & 0.54 & 1.24 & 0.20 \\
\hline Profile average & 45 & 136 & 0.256 & 1.24 & 0.04 \\
\hline $\begin{array}{l}\text { Surface solls } \\
\text { Corn plote* }\end{array}$ & 5 & 20 & 0.12 & 0.18 & 0.08 \\
\hline $\begin{array}{l}\text { Surface solls } \\
\text { Orchard** }\end{array}$ & 1 & 23 & 0.26 & 0.45 & 0.10 \\
\hline
\end{tabular}

*Rayne, Clymer, and DeKalb solls--Bruceton Mills, Date supplied by E. H. Tyner, Department of Agronomy and Cenetics.

**Frankatown--Eesterm Panhandle. Data supplied by R. H. Suddo, Department of Horticulture. 
not extremely low. Six samples from the figronomv Farm at Morgantown average $0.265 \mathrm{~m}$. e. or essentially the average for the state.

One other point should be mentioned concerning the 8 erages given. The samples came from many different parts of the state, but the various soil types are not represented in anything like their proportion to the total area. Gilpin and Ashby, for instance, probably cover almost half of the state, but they represent only about one-tenth of the samples. In general the shale uplan? areas have potash supplies considerably above the average given, except where very strong leaching has occurred.

\section{Relation of Avallable Potash to Organic Suprly Matter}

Surface solls average somewhat higher than subsoils in the present results, and even higher averages have been renorted for 0 to $3-1$ nch layers (Table 6 ), where the organic content is higher than in the entire surface so1l. Th1s, together with the fact that organic materials frequently contain relatively large amounts of potash, ralses the question as to whether the two factors--exchangeable potash and organic matter-are generally associated in West $\pi 1$ rginia solls. Figure 14 shows the relationship obtained with the nresent data.

TABIE 6-DATA FROM ROBINSON (40) FOR PASTURE SOIIS ALL 0 to $3^{\text {" sermples }}$

\begin{tabular}{|c|c|c|c|c|}
\hline \multirow{3}{*}{ SOIL } & \multirow{3}{*}{ SANPIES } & \multicolumn{3}{|c|}{ EXCHANGEABIE POTASSIUM } \\
\hline & & Average & Highest & Lowest \\
\hline & & \multicolumn{3}{|c|}{ m.e. per 100 grams } \\
\hline DeKalb* & 29 & 0.40 & 1.00 & 0.19 \\
\hline Hagerstown** & 13 & 0.32 & 0.51 & 0.19 \\
\hline Upshur & 4 & 0.58 & 0.95 & 0.22 \\
\hline Westmoreland & 2 & 0.35 & 0.44 & 0.25 \\
\hline Elk & 2 & 0.32 & 0.32 & 0.31 \\
\hline Pope & 3 & 0.23 & 0.30 & 0.18 \\
\hline
\end{tabular}

Average ell so11s--0.39.

* Included solls which have now been subdivided into severel series, Including Gilpin, Rayne, Clymer, et cetera.

***Probebly includes some Frederick and Frankstown soils. 


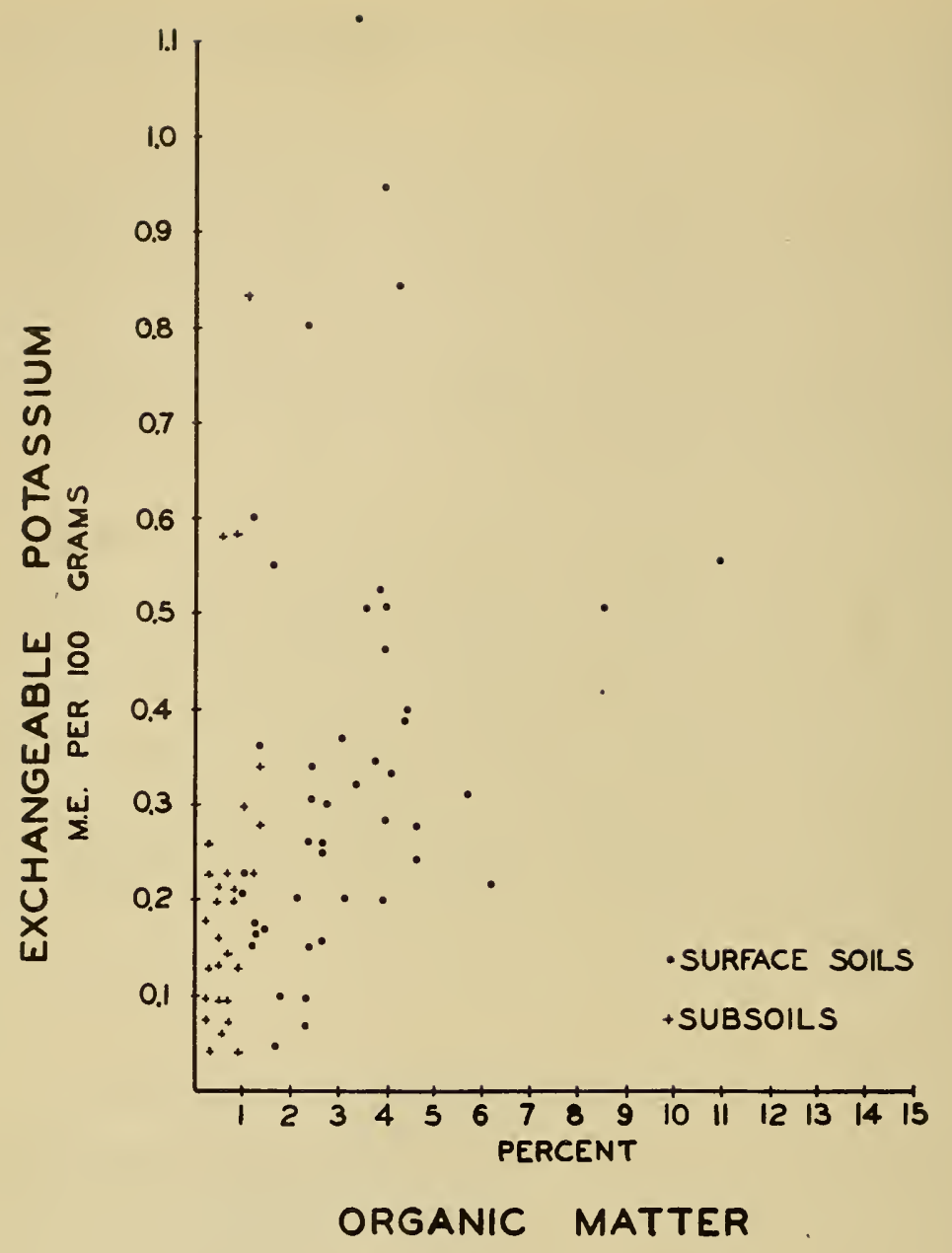

F1g. 14-- Exchangeable potassium valueg for surface solls and subsolle shown in relation to their organic contents. Surface solls seem to be relatively high in exchangeable potash if they ere high in organic metter, but very wide differences occur both with surface and subsolis at low organlc levels. 
With both surface soils and subsoils there is a wide range of values at low organic contents, but it is clear that exchangeable potassium tends to increase with increasing organic content in suriace solls. If the organic supply amounts to more than about 3 percent it appears unlikely that exchangeable potash will ke very low, whereas, with the organic matter much below 3 percent, the available potash may be either very low or very high, much the same as in subsolls. This relationship sugeests an answer to some cuestions regarding the response of pastures to added potash. As shown earlier, the organic reserve in ordinary pastures is quite high in the shallow surface soil, although the total plow layer may be rather low. Since bluegrass and white clover. roots are concentrated mainly in this shallow layer, it is suggested that they ordinarily find abundant potash associated with the organic matter. With alfalfa or corn the deeper root zone would likely be much more deficient.

\section{Avallable Potash Relative to Mineral Content, Suil Type, and Plant Response}

Figure 14 showed wide variations in exchangeable potash which obviously bear no relation to the organic matter supply. These differences seem associated somewhat with clay content, the highest values for subsoils being invariably associated with rather high clay. But clay content as such is not a reliable guide, since certain of the heaviest clays showed low values, and even with some of the high values the total exchange of the clay may be so great that the degree of saturation and the availability will be lower than indicated. This follows from the fact that percentage saturation with potash may be important as well as the total exchangeable supply $(14)$.

In many cases the variation of exchangeable potash within a so11 type has been so great that no conclusion can be drawn as to potash status by soll types. An exception appears to be the Holst on-Nonorgahela solls, which have shown only low values in 22 horizons sampled from 3 profiles. The average is $0.12 \mathrm{~m} . e$. It is to be expected that these solls would show relatively strong response to potash treatment. Pasture plots on one of these sampled profiles, at Nardensville, showed moderate and rather variable response over the area (41*). On erother, near Milton, the pasture showed little or no resporse to potash. Since these solls not only are low in potash

*Also unpublished data. 
throughout but show less concentration of organic mitter in the immediate surface than most other soils (Table l), they would seem to represent an especially favorable condition for potash response. The fact that only variable response was obtained (41) seems to confirm the conclusion of Robinson (40) that potash limitations are not widespread on ordinary surface-treated pastures. But the conclusion obviously does not apply to other crops, and may not even apply to pastures if deeper-rooted pasture herbage is grown in place of bluegrass and clover, especially on soils low in potash like the tholston and Monongahela terraces.

Other highly silty soils without shale fragments have so far shown cuite low potash values. Two profiles of the Erankstown-Pickaway catena from the Greenbrier averaged on $7 y$ 0.15 m.e. for 12 sampled horizons (Table 6). The surface soil of one profile showed only $0.08 \mathrm{~m} . e$. The highest was 0.26 . Another highly silty, stone-free profile, previously designated as Lakin silt loam, averaged $0.12 \mathrm{~m} . e$. in all horizons, having only $0.05 \mathrm{m.e}$. in the surface soil.

Insofar as potash is concerned, these soils seem very Irich like the Holston and Monongahela, although they are unlike in other ways. It would seem that the difficulties with $91 \mathrm{falfa}$ experienced on the Frankstown-Pickaway in the Greerbrier may be related to this low potash supnly along with the generally low base status of these soils already indicated. A low supply and general deficlency of potash has long been associated with the sandy solls of West Virginia and elsewhere, but this indication of exceptionally low values on the very highly silty soils has received less attention. It is noteworthy and possibly significant that examination of the fine sand fractions of these soils under a microscope has failed to reveal any appreciable quantities of muscovite or feldsfars, two of the nrimary sources of soil potash. This suggests that highly silty soils may or may not be deficient in potash in West Virginia, depending to a considerable extent upon whether or not primary notash-bearing minerals are abundant in the fine-sand and silt fraction. If these are not present, the silt is mainly quartz, affording no nutrients. This matter of primary minerals appears to justify further consideration, for in the ordinary shale uplands the notashbearing minerals seem rather abundant; an' exchangeable as well as total potash is relatively high.

Among the acid-shale uplends three Calvin soil profiles show an average of 0.1 m.e. for a sampled horizons (Table 
6). This average is quite low, and the hifhest value, 0.29, comes from a surface soil where the burning of litter may have had an influence, so it seems that the red sheles which give rise to Calvin solis may be associated with potash deficiency, although the variability among these and other acid-shale uplands is such that no defirite conclusions can yet be drawn. Results for Ashby silt loam (Table 6) vary from 0.09 to 0.56 , the high values being associated with hifh organic matter. Gilpin averages somewhat higher, the extreme of $1.0 \mathrm{~m} . \mathrm{e}$. occurring in a shaly sulsoil. These two soils are grouped together in Table 6 because their variability seems to leave Iittle ground for separating the samples sturied, and there is probably no reason to expect any characteistic difference.

Solls with strong limestone influence show moderately high exchangeable-potash cortents, although Hagerstown and Frederick do not average as high as Gilpln, and quite low values were obtained for one typical sample of each. The Jpshur-Meigs results shown are the highest, the extremely high values coming from a lime-rich orofile over a partially red clay-shale. The second profile was more tynical of Upshur in color and appearance and contained no free lime. Its exchangeable potash ranged from 0.20 to $0.35 \mathrm{~m} . \mathrm{e}$.

The slack-water terraces and associated bottom soils Erouped topether averaged rather low. Highest values were from the hieh organic Blago, and lowest for strongly-acid clay subsoil. One slack-water terrace soil with free lime below 40 inches is shown separately, but it is no higher in potash than the acid slack-water solls.

Fertility-plot experiments involving potash response on several solis seem to agree with the tentative conclusions which might be drswn from the chemical data. Alfalfa trials on various solls have shown good response on Holston, Fiankstown, and Wheeling; fair response on some Hagerstown and DeKalb; but little or no response on Westmoreland or MelesUpshur. Alfalfa also responds weil on Rayne-Cooksport solls on the Agronomy Farm at Norgantown. Corn response has generally been less pronounced, but in Preston County, farm trials seem to indicate considerable need for potash on solls containing from 0.08 to $0.18 \mathrm{~m}$.e. of exchangea le potash ner 100 rrams in the surface horizon. The soils are redominantly DeKalb, Clymer, and Rayne and might be expected to show deflciencies. The exchanfestle-potash values mentioned are 

6).*

A large number of trials on Wheeling soil at Iakin indicate that the cropping system and use of manure are important in determining response to potash. In systems where plentiful supplies of manure were returned to the land, potash fertilizer had little effect. However, where no manure was used, crops gave good response to potash. This was particularly true on limed areas, where both legumes and nonlegumes have been increased in yield by the use of potash fertilizers.** Chemical tests for exchangeable potassium would not be expected to show all such differences as these which are associated with cropping and management.

Pasture studies, as already discussed, give some indication of response where potash is very low (Holston-Monongahela, some Rayne) but little indication of a widespread need for potash in bluegrass pastures. The need may become somewhat ereater as more deep-rooted legumes and grasses are used in place of Kentucky bluegrass and white clover.

Greenhouse tests with several subsolls have shown much less response to potash then to phosphorus. Acid, shaly ucland; clay derived from limestone, and slack-water clay materials have been involved in these tests.

\section{DISCUSSION}

In order to attain maximum profitable production over a long period it is necessary to make all of those factors influencing production as favorable as is economically possible. The factors for which data are presented are among the more important in West Virginia but are by no means the only factors to be considered. However, weter and air relationships, soil structure, acidity and base content, organic matter supply, and content of available plant food must be favorable for the crops to be grown if the goal of maximum nrofitarle production is to be achieved. There are two approaches to this problem--orops may be selected which will thrive under the conditions as found, or soil conditions may be changed so that the desired crops may be grown (23).

\footnotetext{
*These data supplied by Dr. Edward H. Tyner, Department of Agronomy and Genetics, West Virginia University. * Unpublished data.
} 
Fortunately nature has provided plants for almost every soll and climatic condition known to man. It is therefore possible to select plants for the various conditions as they occur, whether these conditions be natural or the result of man's interference in nature's scheme. Actuall., under the climatic conditions in West Virginia the mere protection of the soll and vegetation from abuse will usually result in adequate cover for the conservation of the soll and will at the same time provide some production. However, under many and perhaps most conditions the production thus obtained will be meager. Increased production can often be obtained by introducing crops which are adapted to the conditions. This fact has been responsible for the introduction and development of many plants which are adapted to a wide range of conditions. One example of this practice has been the introduction of the lespedezas into the agriculture of the southeastern part of the United States.

Unfortunately it has not been possible thus far to discover a sufficient variety of crops of the kind which satisfy the needs of agriculture under prevaling conditions of high acidity and low fertility. Some will serve a very useful purpose under certain conditions. Others may also be temporirily useful and for a time may prove to be the most profitable crops. But so far as is known at present there is no good substitute for favorable soll conditions.

The second alternative, 1.e., changing soil conditions so that growth of better plants is encouraged, is usually the more desirable for long-time profitable agriculture. Under most conditions it is desirable to improve surface-soil structural conditions, air and water relationships, orgenicmatter supply, and plant-food content so that those crops can be grown which will give the maximum profitable production. To do this may require only a few simple practices or many different practices, depending on the soil.

It is evident from the data given that, al though there is considerable variation within soils of the same series, there are even greater differences in certain vroverties between the different soil series. Certain solls appear to have many factors favorable for high production, whereas others are apparently lacking in several respects. For example, the Hagerstown solis have, in general, a favorable structure along with a hizh content of bases. Such solls will therefore be kept in a nroductive state by applying the plantfood elements needed, by keening an active org:nic matter sun- 
ply, and by using such practices as mey be necessary to prevent loss of the surface soll by erosion. Since these soils are not so highly leached as many of the others, the need for adder plant food is probably not so great. On the other hand, most of the other solls have less favorable structure, which in itself is a handicap, and lower quantities of bases. In adilion some or the solls have less organic matter, less avallable plant food, and poorer air/water relationships, all of which must be dealt with in bringing the soils into a high state of productivity. Recognition of these variations between solis is of utmost importance both in planning and conducting experimental work and in planning for proper land use on the individual farm. Too often in conducting experiments in which the soll is one of the factors there has been a tendency to concentrate on a perticular set of treatments being studied and to forget about the soil. As a result certain data are obtained which may have only very limited apsilcation because the soll on which they were obtained represents only a small area. For example, some experiments at Kearneysville showed good growth of alfalfa on a fairly acid soll. The reason for this was undoubtedly associated with the presence of lime in the subsoll, but tests of the surface soils dia not show this. From this experiment, if other information had not been av9117ble, one might have concluded that lime was not necessary for alfalfa. Ilkewise, for some years different varieties of oats have been recommendej for soils which had a plentiful supply of nitrogen than for the soils which are not so well supplied with this element. Hybridcorn verieties, too, differ in their response to different levels of fertility, some being superior at high levels, whereas others, which are only mediocre at high levels of fertility, may be among the best at lower fertility levels. Other examples could be cited, but these are sufficient to establish the importance of the factor of soil fertility in relation to field response. From these it seems apparent that, in order to be able to interpret experimental results oroperly and, in fact, in order to secure experimental results which will be most helpful to famers, it is necessary to conduct such experiments under a considerable range of soil conditions. Even when this is done there will still be many ouestions which will require additional research and proper interpretation for their proper solution. But the number and importance of the unanswered questions will decrease as our knowledge of the solls increases.

What has been said about planning experimental work is just as true in planning the renacement of the soils on the in. 
dividual farm. Such problems as lime content, plant-nutrient supply, drainage, and physical condition must be considered in any program of farm planning. The relative importance of the various factors will vary with the soil. On some solls lack of lime and fertility may be dominant; on others drainage or erosion control may be of prime 1mportance. Regardless of which factor or group of factors appears most important, all factors must be considered if the results are to be of permanent value and if crop production is to be most prof1table.

For many years certain areas have been recognized as being good farming sections and other areas as being poor farming areas. In general the delineation of these areas appears quite exact and proper because, as has been said, certain soils have a more favorable combination of factors than others. Despite this general recognition there are poor farms in good areas and good farms in the poor areas. In the first case, the farmer has probably falled to recognize one or more of the factors limiting his production and as a result production has declined. On the other hand, the rood farm in the poor area is usually an example of the farmer recosnizing the important factors limiting production and then taking steps to eliminate these factors. As a result over a period of years the good farmer has been able to increase production and at least temporarily overcome the major factors limiting production. This fact should lend encouragement to other farmers who can do equally well if they will follow the orinciple of seeking out the limiting factors and then taking steps to correct the conditions limiting production. Agricultural workers, too, can often learn much about improved methods of soil management from a successful farmer.

\section{SUMMARY AND CONCIUSIONS}

Soll-profile samples were taken from a number of the more important soil series occurring in West Virginia. These samples were taken from sites carefully selected to be typical of the soll as mapred in the state. Determinations of texture, structure, organic matter, pH, buffer curves, exchange capacity, exchangeable bases, and acid-soluble phosphorus were made in the laboratory. Color was defined by field observation and by comparison with color charts.

Most of the surface soils were loams or silt loams with clay or clay-loam subsoils. Structural profiles are shown for certain groups of series, and the relationship of structure to movement of air and water, to soll erosion, and also to 
root penetration is pointed out. The distribution of organic matter in the soil profile is given for a number of series, and the effect of climate and past treatment on organic matter content is discussed.

The relationship between $\mathrm{pH}$, percent saturation, and total bases is given for the major series. These show considerable variation within series as well as between series. Within the soil profiles certain series increase in base content and percent saturation (particularly Hagerstown and Frederick) others show little change, and some show increased acidity and decreased saturation with incre'sing depth. The relationship of this to growth of certain crops is discussed.

The relationship between exchange capacity, and organic metter and clay content is shown, and a general guide is given for evaluating this relationship.

The avallable phosphorus content was renerally low, but a few subsoll samples have shown high contents of acid-soluble phosphorus. These do not seem necessarily to indicate high available phosphorus contents, as some of these soils have shown marked responses to phosphate fertilizers.

Exchangeable potash values range from low to high with an average of $0.256 \mathrm{~m} . e$. of potassium ner 100 grams of so1l. Iow rotash values occur especially in hichly leached terrace solls in sandy soils, in the silty limestone solls, and in old ridge top soils. Jurface solls were usually higher in exchangearle cotash than subsoils. High potash content was usually assoclated with high organic matter in the soil or with high clay content, but the reverse was not always true.

The relationship of the various factors to land use are discussed. In any program of research or farm planning, the chemical composition and physical make-up of the soll must be considered to make such programs most effective. By considering these, together with management on the farm, agricultural workers and farmers can make great progress in wise land use and increased agricultural production. 


\section{BIBI I CGRAPHY}

1. Albrecht, W. A. Adsorted lons on the colloidal complex and plant nutrition. Soll Sci. Soc. Amer. Proc. 5: 8-16. 1940.

2. Paver, L. D. The effect of organic matter upon several physical properties of soils. Jour. Amer. Soc. Agron. 22: 703-708.

3. The nature of soil buffer action. Jour. fimer. Soc. Agron. 23: 587-605. 1931.

4. Soll Physics. John Wiley \& Sons. New York. 1940.

5. Bear, F. E., and Salter, R. M. Methods in soil analysis. W. Va. Agr. Exp. Sta. Bul. 159. 1916.

6. Bray, R. H., and Whilhite, F. M. Determination of total replaceab]e bases in solls. Ind. and Ene. Chem., Anal. Ed. 1: 144. 1929.

7. Brown, D. S. Robirson, R. R., and Browning, F. M. Determination of small amounts of potassium. Ind. and Eng. Chem., Anal. Ed. 10: 652-654. 1938.

8. Browning, G. M. A comprarison of the dry combustion and the rapid titration methods for determining organic matter in soll. Soil Sc1. Soc. Amer. Proc. 3: 158161. 1938 .

9. and Vilam, F. M. A comparisor $n$ the Briggs-McIane and the Goldbeck-Jackson centrifuge methods for determining the moisture equivalent of solls. Soil Sc1. 51: 273-278. 1941.

10. Effect of different

types of organle materials and lime on soil aggregat1on. Soil Sc1. 57: 91-106. 1944.

11. and Sudds, R. H. Some physical and chem1cal properties of the principal orchard soils of the Eastern Panhandle of West Virginia. W. Va. Agr. Exp. Sta. Bul. 303. 1942.

12. Bryan, O. C., and Deatrick, E. P. Chemical analyses and fertility of West Tirginia soijs. ". Va. Arr. Fxp. 
Sta. Eul. 1E4. 1924.

13. Bushnell, T. M. An outline of the classification of Indiana soils. Indiana Acad. of Sci. 49: 15l-158. 1940.

14. DeTurk, E. E. The effective use of potash fertilizers during the war. Soil Sci. Soc. Amer. Proc. 8: 46-53. 1943.

15. Duley, F. L., and Felly, I. I. Effect of soil type, slone, and surface conditions on intake of water. Nebr. Agr. Exp. Sta. Res. Bul. 112. 1939.

le. Free, G. R., Browning, G. M., and Musgrave, G. W. Relative infiltration and related physical characteristics of certain soils. T.S.D.A. Tech. Bul. 729. 1940.

17. Galpin, S. L. "Blister" slips in West Virginia. Soil Sci. Soc. Amer. Proc. 5: 418-420. 1940.

18. Personal communication.

19. Hunger Signs in Crops, The Amer. Soc. of Agron, and the tional Fertilizer Assoc., Washington, D. C. 1941.

2C. Jenny, H. Factors of Soil Formation. McGraw-Hill, I. Y. 1941.

21. Kappen, H. Die Bodenaziditët. Verlag von Julius Springer, Berlin. 1929.

22. Kellogg, C. E. Development and significance of the great soij groups of the United States. U.S.D.A. Misc. Pub. 229. 1936.

23. Soil and Society. U.S.D.A. Yearbook (Soils and Men): $863-886.1938$.

24. The soils that support us. The vacmillan Co., N. Y. 1941.

25. Krusekopf, F. H. The hardpan solls of the Ozark region. Soil Sci. Soc. Amer. Proc. 7: 434-436. 1942.

26. Lamb, J., Jr., and Chapman, J. E. Effect of surface stores on erosion, evaporation, soil temperature, and soll moisture. Jour. Amer. Soc. Agron. 35: 567-578. 1942. 
27. NeIlvaine, T. C., and fohlmen, G. G. Crop rotation experlments in the Ohio Valley. W. Va. Agr. Exp. Sta. Bul. 306. 1943.

28. Mehlich, A., and Colwell, W. E. Influence of nature of soll colloids and degree of base saturation on erovit? and nutrient uptake by cotton and soybeans. Soll Sci. Soc. Amer. Proc. 8: 179-184. 1943.

29. Middleton, H. E. Properties of solls which influence erosion. T.S.D.A. Tech. Bul. 178. 1950.

30. Nitchell, J. The origin, nature, and importance of soil organic constituents having; base exchange properties. Jour. Amer. Soc. Agron. 24: 256-275. 1932.

31. Nikiforoff, C. C. Hardpan ond microrellef in certain soil complexes of California. U.S.D.A. Tech. Bul. 745. 1941.

32. Norman, A. G., and Bartholomew, ii. V. The chemistry of soll organic matter: I. Distribution of uronic carbon in some profiles. Soll Sci. 56: 143-150. $194 j$.

33. Plerre, W. H., and Wo:ley, S. L. The buffer method and the determination of exchangeable $\mathrm{H}$ for estirating the amounts of lime reçuired to bring soils to definite $\mathrm{p}$ 다 values. Soll Sc1. 26: 368-375. 1928.

and Scarseth, G. D. Determination of the percentage base saturation of soils and its value in different solls at definite $\mathrm{pH}$ values. Soll Sc1. 31: 99-114. 1931.

35. and Allaway, W. H. Calcium in the soil: II. BIological relations. Soll Sci. Soc. Amer. Proc. 6: 16-26. 1941.

36. Tohlman, G. G. Iand classification in West Tirginia based on use and agricultural value. W. Va. Agr. Exp. Sta. Bul. 284. 1937.

37. Olmstead, I. B., Alexander, I. T., and Middleton, F. I. A pipette method of mechanical analysis of solls, based on improved dispersion procedure. J.S.D.A. Tech. Bul. 170. 1930. 
38. Olsen, S. R., and Shaw, B. T. Chemical, Mitscherlich, and Neubauer methods for determining avallable potassium in relation to crop response to potrsh fertilization. Jour. Amer. Soc. Agron. 35: 1-9. 1943.

39. Rice, T. D., Nickerson, Dorothy, O'Neal, A. M., and Thorp, James. Preliminary color standards and color names for solls. U.S.D.A. Misc. Pub. 425. 1941.

40. Robinson, R. R. Soil properties determining the botanical composition of pastures in West Virginia. Jour. Agr. Res. 54: 877-897. 1937.

41. and Plerre, W. H. Response of permanent pastures to lime and fertillzers (1930 to 1936). W. Va. Agr. Exp. Sta. Bul. 289. 1938.

42. Selter, R. M., and Wells, ${ }^{\circ}$. F. Analyses of West V1rginia solls. W. Va. Agr. Exp. Sta. Bul; 168. 1918.

43. Smlth, R. M. Some effects of black locust and black walnuts on southeastern Ohio pastures. Soil Sci. 53: 385-398. 1942 .

44. Sm1th, Fenry W., and Weldon, M. D. A comparison of some methods for the determination of soll organic matter. Soll Sc1. Soc. Amer. Proc. 5: 177-182. 1940.

45. Smith, R. M., Browning, D. R., and Pohlman, G. G. Iaboratory percolation through undisturbed soil samples in relation to pore size distribution. Soll Sc1. 57: 197-213. 1944.

46. So1l Survey, Greenbrier County, "est $\Pi 1$ rglnia. U.S.D.f. So1l Survey Rpts., Series 1937, No. 3. 1941.

47. Stelly, N., and Plerre, W. H. Forms of 1norganic phosphoms in the C horlzons of some Iowa solls. Soll Sc1. Soc. Amer. Proc. 7: 139-147. 1942.

48. Truog, E. The determination of the readily avallable phoschorus of soils. Jour. Amer. Soc. Agron. 22: 874-882. 1930.

49. Weltzel, E. C., and Miller, I. F. Forest-land ut1lization in Nicholas and Webster counties. W. Va. Agr. Fixp. Sta. Bul. 309. 1943. 
50. Wirters, Eric. Silica hardpan develonment in the red and yellow podzolic soll reglon. Soll Sc1. Soc. Amer. Proc. 7: 437-440. 1942 .

51. Yoder, R. E. A direct method of aggregate analysis of solls and a study of the physical nature of erosion losses. Jour. Amer. Soc. Agron. 28: 337-351. 1936. 





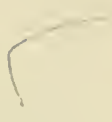


